\title{
3. 1985-2003: estagnação, crise e crescimento
}

\section{De 1985 ao fim da década}

\section{Criação da União dos Produtores de Bioenergia (UDOP)}

A União dos Produtores de Bioenergia (UDOP), fundada em 1985 pelos diretores das destilarias autônomas criadas com o Proálcool, tinha como objetivo propiciar a troca de informações entre seus diretores, além de capacitar profissionais para as unidades e proporcionar a troca de conhecimentos e informações por meio das reuniões dos comitês técnicos instituídos. Segundo Antonio César Salibe, a formação de capital humano era considerada chave para a boa operação das usinas, de modo que um programa de capacitação foi criado. Nos últimos trinta anos, a UDOP formou mais de 100 mil pessoas, ainda de acordo com Salibe ${ }^{1}$.

\section{5-1986: uma vitória na guerra comercial do etanol}

Em 1985, o Brasil foi acusado na International Trade Commission (ITC), em Washington, de exportar etanol aos EUA aproveitando-se de subsídios governamentais e praticando dumping de preço. Para coordenar a defesa contra as duas ações (direitos compensatórios e anti-dumping), os produtores brasileiros organizaram o Comitê Especial de Exportação dos Produtores Brasileiros de Álcool, com a seguinte composição: Lamartine Navarro Júnior, André Francisco de Andrade Arantes,

1 Para mais informações, ver $<$ www.udop.com.br/>. 
João Guilherme Sabino Ometto, Pedro Biagi Neto, José Carlos Maranhão, Cláudio de Veiga Brito, Fernando de la Riva Averhoff e Plínio Nastari (coordenador).

Nas duas ações, os produtores e as trading companies envolvidas tiveram que passar pelos testes de dano e de ameaça de dano. No teste de dano foi avaliado que o efeito residual dos subsídios ao Proálcool era de 2,63\% sobre o valor da produção em 1984, considerado de minimis; também não foi aceita a alegação de ameaça de dano aos produtores norte-americanos.

Segundo comunicação de Sergio C. Trindade, a vitória do Brasil nessas ações teve ajuda insuspeitada de um estudo de Trindade (1984) demonstrando a ausência de dumping, adquirido pelos advogados americanos (Akin, Gump, Strauss, Hawer \& Feld) contrários ao Brasil para buscar argumentos a seu favor. Quase três décadas depois, os esforços da União da Indústria de Cana-de-Açúcar (Unica) resultaram na abertura dos mercados de etanol do Brasil e dos EUA em 2011.

\section{Criação da Sociedade Brasileira de Biotecnologia (SBBiotec)}

Em 1988, deu-se a criação da Sociedade Brasileira de Biotecnologia (SBBiotec) ${ }^{2}$ e da Rede Brasileira de Biotecnologia (RBBiotec) ${ }^{3}$, com o objetivo de "promover o progresso da biotecnologia, por meio do desenvolvimento científico e tecnológico, integrados para possibilitar a capacitação industrial do setor produtivo e de serviços, visando ao desenvolvimento do País e ao bem maior da Sociedade Brasileira" ${ }^{4}$.

\section{Criação do Consórcio Internacional para a Biotecnologia da Cana-de-Açúcar}

Manoel Sobral Júnior (Figura 31), então diretor do Centro de Tecnologia Canavieira (CTC) e responsável por iniciativas pioneiras na pesquisa aplicada às usinas, criou, em 1988, o Consórcio Internacional para a Biotecnologia da Cana-de-Aç úcar (International Consortium for Sugarcane Biotechnology - ICSB) que levou ao mapeamento genético da cana, processo extremamente importante no desenvolvimento de novas variedades.

\footnotetext{
Para mais informações, ver $<$ www.sbbiotec.org.br/v3/>.

Para mais informações, ver $<$ www.rbbiotec.org.br $>$.

Conforme o estatuto da SBBiotec, disponível em: <www.sbbiotec.org.br/v3/sbbiotec/estatuto/>.
} 
Segundo o diretor técnico da União da Indústria de Cana-deAçúcar (Unica), Antônio de Pádua Rodrigues, "O setor deve muito ao trabalho competente e às iniciativas sempre produtivas do Manoel Sobral, uma pessoa que tem tudo a ver com o progresso e as realizações do CTC".

\section{9: maior crise do Proálcool ${ }^{5}$, faltou álcool...}

O fim da década de 1980 foi marcado por um descompasso entre a produção de veículos a álcool e a correspondente produção de álcool. No fim do regime militar, em 1985, a produção de veículos a álcool já era significativa e, devido à crise econômica que dominou os anos 1980 e o controle de preços que imperava para controle da inflação ${ }^{6}$, poucos investimentos foram realizados na produção de álcool. $\mathrm{O}$ percentual de carros a álcool (E100) ${ }^{7}$, em relação ao total produzido, alcançou $90 \%$ já em meados da década.

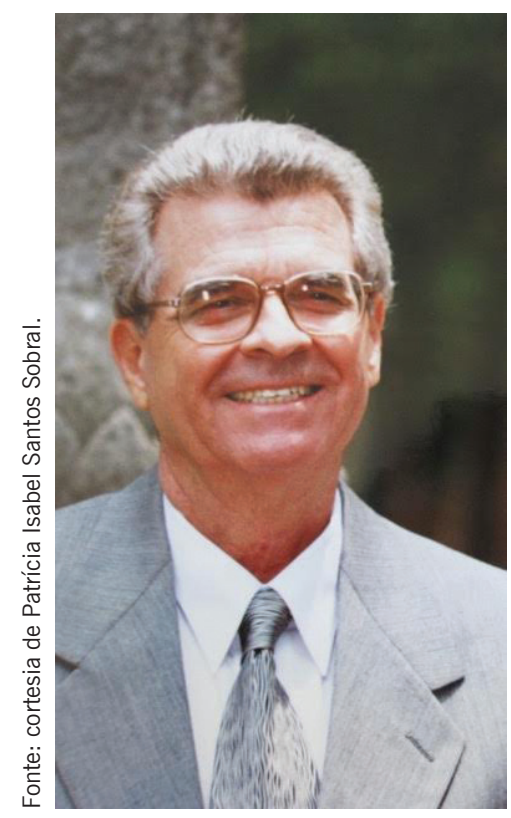

Figura 31: Manoel Sobral Júnior.

Se por um lado isso era positivo, pois fazia o país economizar divisas, por outro trazia o risco da falta de álcool no mercado.

Foi o que aconteceu em 1989, quando faltou álcool devido à ausência de planejamento combinado à alta dos preços do açúcar no mercado externo. Para suprir esse déficit, o governo decidiu importar metanol (Azevedo; Borges, 1990) para formular uma mistura ternária (33\% de metanol $+60 \%$ de etanol $+7 \%$ de gasolina), chamada de MEG, que serviu para amenizar a escassez do etanol, permitindo o funcionamento

5 Embora o programa de subsídios tenha terminado em 1985, e esta data possa ser considerada de término do Proálcool, o termo "Proálcool" continuou a ser empregado designando o esforço do setor, da academia e do governo para o desenvolvimento de tecnologias e disseminação do uso do etanol combustível no Brasil.

6 Segundo técnicos do setor, o governo federal tabelava os preços dos combustíveis e não oferecia condições satisfatórias para a comercialização do etanol.

7 A denominação oficial dada pela Agência Nacional do Petróleo (ANP) é álcool etílico hidratado combustível (AEHC), e não E100, pois o combustível tem presente, aproximadamente, $7,5 \%$ de água em sua composição em massa. No entanto, a designação E100 significa que o combustível é composto por $100 \%$ de etanol. 
normal dos automóveis produzidos para usar etanol hidratado. Segundo técnicos do setor, a mistura MEG permitia economia de etanol e possibilitava desempenho equivalente ao do etanol hidratado. A formulação final da mistura foi ajustada pela Cetesb de modo a não alterar a emissão de gases poluentes regulamentados, e a indústria automobilística aceitou a nova especificação do combustível sem alteração da garantia dos veículos.

Um estudo encomendado pelo governo federal a José Roberto Moreira, Alfred Szwarc e Paulo Saldiva demonstrou a viabilidade técnica e a segurança ambiental e à saúde do uso da mistura combustível. Ressalte-se o papel de György Miklós Böhm, da Escola de Medicina da USP, nesse estudo.

Apesar da toxidez do metanol e da consequente polêmica que precedeu o uso da mistura MEG, o uso desse combustível não resultou em maiores riscos para a saúde pública e para o meio ambiente e tampouco resultou em acidentes pessoais. Entretanto, a escassez do etanol, mesmo durante apenas alguns meses, levou a um descrédito do carro a álcool, fazendo suas vendas despencarem e trazendo de volta o interesse pelo carro à gasolina, o que levou as montadoras a desistirem de investir na evolução do carro a álcool.

Vê-se depois, já no início da década de 1990, uma queda na demanda por álcool hidratado e a elevação, proporcional, do consumo de álcool anidro adicionado à gasolina, em consequência das mudanças no mercado de combustíveis para veículos leves no país.

\section{Final da década de 1980: a empresa Bosch inicia a pesquisa sobre o motor bicombustivel no Brasil}

\footnotetext{
A crise de desabastecimento de álcool no Brasil, ocorrida no final da década de 1980, levou uma equipe de engenheiros do escritório brasileiro da empresa Robert Bosch a avaliar que o bicombustível seria uma solução para o país. A filial norte-americana da empresa já possuía uma patente de 1988 sobre uma técnica de detecção de combustível por meio do uso de sonda de oxigênio, que media a condutividade elétrica do ar e estabelecia uma correlação com a quantidade de oxigênio presente no reservatório (Teixeira, 2005).
}

As pesquisas mencionadas por Teixeira seriam a base para o desenvolvimento da tecnologia flex-fuel no Brasil. 


\section{A década de 1990}

\section{0: a revista Brasil Açucareiro deixa de ser publicada}

O Instituto do Açúcar e do Álcool (IAA), criado na década de 1930, forneceu uma grande contribuição à pesquisa da bioenergia no Brasil ao publicar a partir de 1935 a revista Brasil Açucareiro, descontinuada em 1990 com a extinção do IAA (Figura 32).

Também a Sociedade dos Técnicos Açucareiros e Alcooleiros do Brasil (STAB) tem publicado sua revista voltada para o público técnico e representando, atualmente, o único canal especializado existente no país com essas características. Um inventário das publicações, realizado por Vian e Corrente (2007), possibilita uma melhor compreensão dos meios de difusão das pesquisas realizadas no setor.

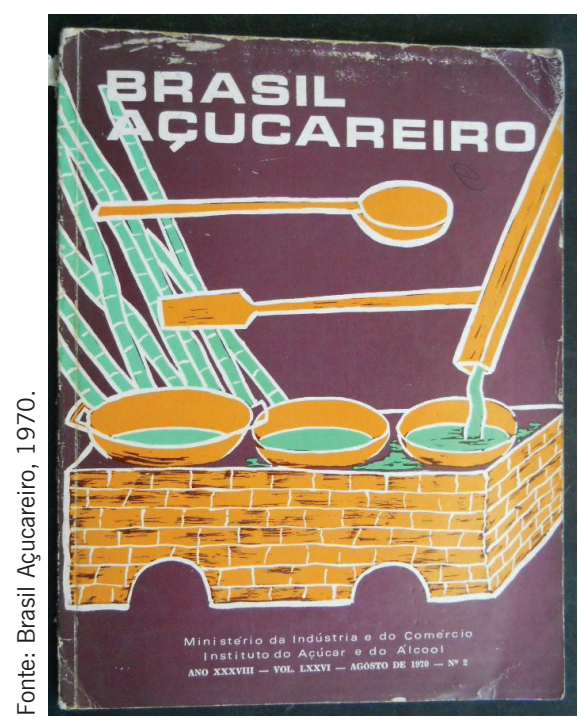

Figura 32: Brasil Açucareiro (edição de 1970).

\section{1: criação do Programa de Pós-Graduação Interunidades em Biotecnologia (PPIB) ${ }^{8}$}

É criado, em abril de 1991, o Programa de Pós-Graduação Interunidades em Biotecnologia (PPIB), da Universidade de São Paulo (USP), por três instituições: a própria USP; o Instituto Butantan, da Secretaria de Saúde do Estado de São Paulo (IB); e o Instituto de Pesquisas Tecnológicas do Estado de São Paulo (IPT).

Entende-se por biotecnologia "qualquer aplicação tecnológica que use sistemas biológicos, organismos vivos ou derivados destes, para fazer ou modificar produtos ou processos para usos específicos" (Convenção sobre Diversidade Biológica da ONU, 1992)9.

8 Ver $<$ http://sites.usp.br/biotecnologia/programa/apresentacao-2/>.

9 Ver <www.mma.gov.br/biodiversidade/convencao-da-diversidade-biologica $>$. 
Segundo a apresentação do programa:

Quanto aos seus objetivos, o PPIB foi concebido visando garantir a interdisciplinaridade indispensável à Biotecnologia, em toda a sua abrangência. Para proporcionar formação adequada, é necessária a consolidação de competências específicas de diversas áreas do conhecimento, como, Genética, Biologia Molecular, Biologia Celular, Microbiologia, Engenharia Bioquímica, Bioquímica, Tecnologia da Informação, Biossegurança, Bioética, entre outras. Além disso, a organização interinstitucional possibilita que institutos com vocação científico-tecnológica, como o Instituto Butantan e o Instituto de Pesquisas Tecnológicas, participem, junto com a Universidade de São Paulo, na formação de profissionais com um perfil adequado para a área aplicada.

\section{2: extinção do IAA e desregulamentação do setor sucroalcooleiro}

O IAA foi extinto pelo presidente Fernando Collor de Mello por intermédio do Decreto n. 99.240. Com a extinção do IAA e do Planalsucar, criou-se a Rede Interuniversitária para o Desenvolvimento do Setor Sucroenergético (Ridesa) ${ }^{10}$, integrada pelas universidades UFPR, UFV, UFSCar, UFG, UFRPE, UFAL e UFRRJ, que conta com 34 estações e é responsável pelas variedades RB de cana-de-açúcar.

Destacaram-se na montagem da nova organização os pesquisadores Marcos Sanches, Octávio Antonio Valsechi e Hermann Hoffman, da UFSCar.

Atualmente, as variedades RB ocupam cerca de 70\% das áreas plantadas com cana no país. A UFSCar criou sua estação experimental no campus de Araras, para cursos em ciências agrárias, na fazenda do extinto Planalsucar, a fim de também desenvolver seu Programa de Melhoramento Genético de Canade-Açúcar (PMGCA) ${ }^{11}$.

O ano de 1992 também assistiu à criação da DZ Engenharia, Equipamentos e Sistemas. As tradicionais empresas do setor sucroalcooleiro, Dedini e Zanini, decidiram somar forças e formaram a DZ Engenharia, Equipamentos e Sistemas, maior fábrica mundial de equipamentos para o mercado de açúcar e álcool.

10 Ver <www.ridesa.agro.ufg.br/>.

11 Ver $<$ http://pmgca.dbv.cca.ufscar.br/>. 


\section{4: Criado o Programa Cana IAC, da APTA}

Já o IAC, vinculado à Agência Paulista de Tecnologia dos Agronegócios (APTA), da Secretaria de Agricultura e Abastecimento (SAA) de São Paulo, mantém hoje uma posição de destaque no setor e tem sido responsável pelo lançamento das variedades IAC, assim como de outras tecnologias na área agronômica, como a "matriz de ambientes", que dá apoio ao manejo varietal, e a técnica das mudas pré-brotadas (MPB), que trouxe um novo conceito de produção de mudas e gestão espacial de touceiras de cana.

O Programa Cana IAC foi criado em 1994, redesenhando o modelo de pesquisa do Instituto Agronômico em cultura da cana-de-açúcar, que datava do início do século XX. Para tanto, estabeleceu-se um centro virtual que coordenava uma ampla ação em network para desenvolvimento de variedades e outras tecnologias, a partir da unidade de Ribeirão Preto, depois transformada em Centro Cana IAC (em 2005), dirigida por Marcos Guimarães de Andrade Landell. Esse programa de pesquisa mantém convênio de integração técnico-científica com aproximadamente 180 instituições (universidades e institutos de pesquisas) e empresas parceiras, consideradas para efeito de gestão como "unidades de pesquisas".

Destacam-se algumas das contribuições do Centro Cana no recente livro Cana-de-Açúcar (Dinardo-Miranda, Vasconcelos e Landell, 2008), que indica importantes tecnologias desenvolvidas pela equipe do Programa Cana IAC na área de nutrição, de entomologia e nematologia, matologia, defesa fitossanitária etc. (Figura 33). O Polo Regional Centro-Sul da APTA, em Piracicaba (SP), é um dos centros de experimentação para desenvolvimento de novos cultivares e técnicas de manejo da cana-de-açúcar. O início do trabalho de melhoramento genético do Programa Cana do IAC é realizado em Uruçuca, próximo a Ilhéus, na Bahia. É lá que o IAC mantém uma das mais modernas estações de hibridação do mundo. Em 2015, foram efetivados 626 cruzamentos que, no futuro, vão gerar variedades para modernizar a canavicultura brasileira.

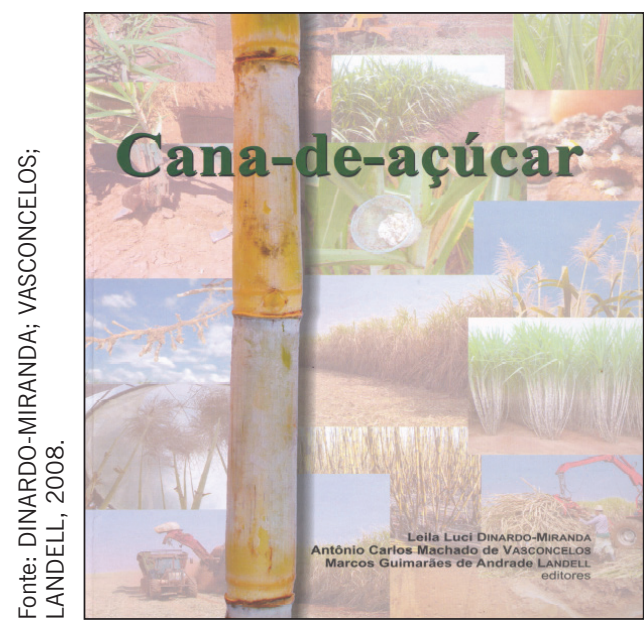

Figura 33: Livro Cana-de-açúcar, publicado em 2008 pelo Centro Cana. 


\section{Programas de melhoramento de cana no Brasil}

Atualmente, existem quatro programas de melhoramento genético de cana convencional no Brasil: IAC/ APTA, CTC, RIDESA e Syngenta. Um exemplo do sucesso alcançado com os programas de melhoramento é a evolução da produtividade agrícola experimentada pela cana no país (Figura 34). A empresa Canavialis, que havia sido adquirida pela Monsanto, encerrou suas atividades em outubro de 2015.

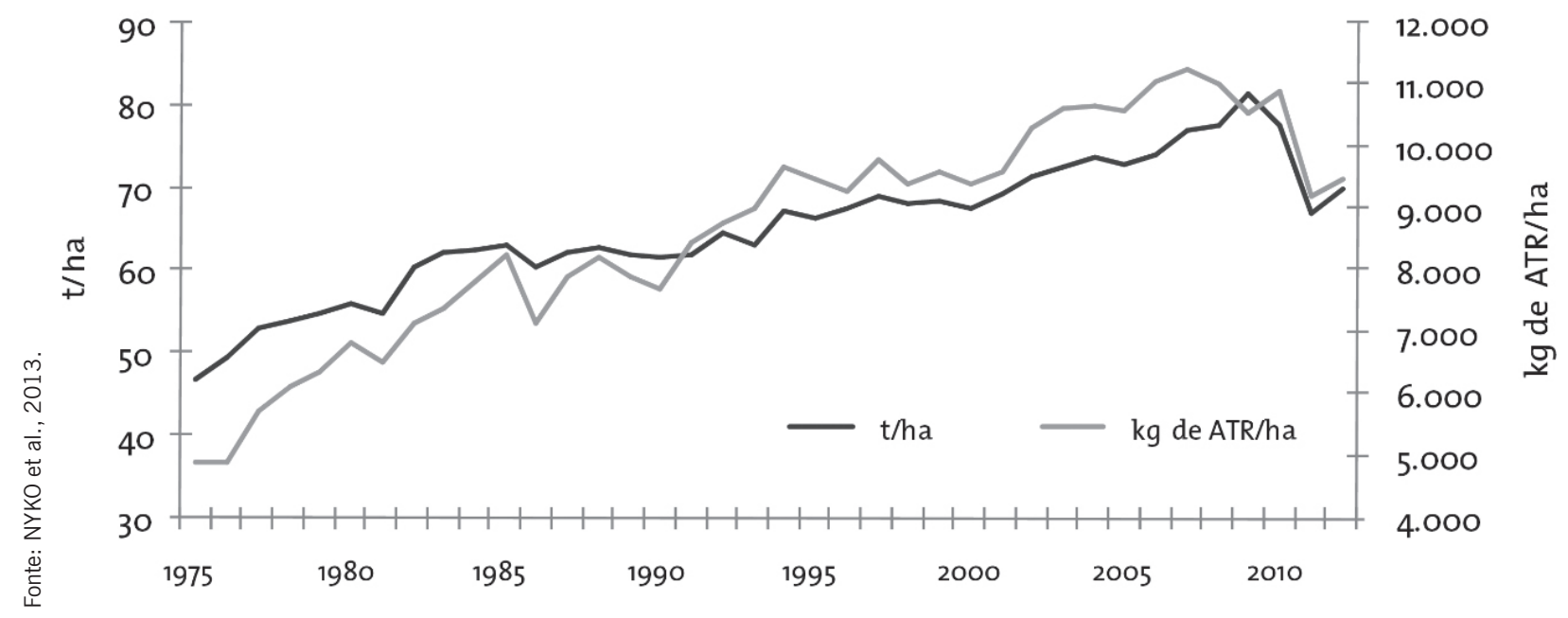

Figura 34: Evolução da produtividade agrícola da cana-de-açúcar entre 1975 e 2010 no Brasil.

\section{Controle biológico das pragas da cana-de-açúcar}

O Programa de Controle Biológico das pragas da cana-de-açúcar no Brasil é considerado um dos maiores do mundo, pois quase metade da área plantada no país tem sido tratada com agentes de controle biológico. Quem iniciou tal programa, criando a "cultura" do controle biológico, foi Domingos Gallo, do Departamento de Entomologia da ESALQ/USP, que já nas décadas de 1950-1960 começou a utilizar moscas nativas para controlar a broca-da-cana, Diatraea saccharalis. Posteriormente, na década de 1970, foi importada a Cotesia flavipes (na época era Apanteles flavipes) de Trinidad e Tobago e Paquistão para controlar tal broca. 
Os trabalhos tiveram sequência com o desenvolvimento de métodos para a criação da broca em dieta artificial para liberação nos campos. Tais programas foram conduzidos pela Planalsucar e Copersucar, e os insetos eram produzidos especialmente em laboratórios das próprias usinas. Mais recentemente, surgiram empresas que comercializam tais agentes de controle biológico.

A partir da década de 1980, o grupo da ESALQ, liderado por José Roberto Postali Parra (Figura 35), passou a estudar um parasitoide de ovos da broca, Trichogramma galloi, para ser utilizado ao lado de Cotesia flavipes. Hoje são cerca de 3,5 milhões de hectares tratados com C. flavipes e cerca de 500 mil hectares tratados com T. galloi para controlar a broca-da-cana. Além disso, atualmente é bastante utilizado o fungo Metarhizium anisopliae, produzido e comercializado por empresas especializadas - mais de 2 milhões de hectares são tratados com esse agente de controle biológico. Para controlar a cigarrinha-da-cana, emprega-se Mahanarva fimbriolata no Sudeste e em outras áreas e Mahanarva posticata no Nordeste do país.

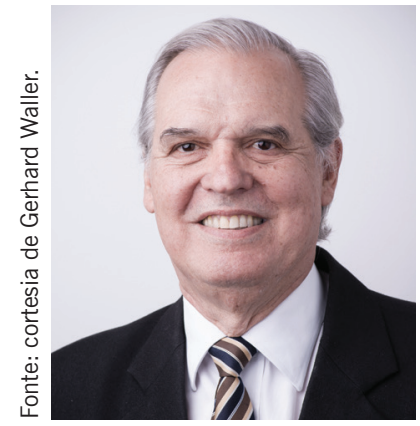

Figura 35: José Roberto Postali Parra.

O Metarhizium começou a ser estudado por Pietro Guagliumi, da Organização das Nações Unidas para Agricultura e Alimentação (FAO), no Nordeste do país na década de 1970 e, posteriormente, as linhagens do referido fungo foram melhoradas por Sérgio Batista Alves, da ESALQ/USP (Parra apud Cortez, 2010).

Destacaram-se também Wilson R. T. Novaretti, Enrico B. Arrigoni, do CTC, e Leila Luci DinardoMiranda, do IAC/APTA.

\section{5: a Embrapa realiza pesquisas sobre a fixação de nitrogênio}

Robert M. Boddey, da Embrapa Agrobiologia, publicou Biological Nitrogen-Fixation in Sugar-cane - a Key to Energetically Viable Biofuel Production. De acordo com Boddey, estudos sobre o balanço de N-15 e $\mathrm{N}$ para algumas variedades de cana revelaram que altas produtividades são possíveis sem fertilização de nitrogênio porque as plantas seriam capazes de obter contribuições significativas de nitrogênio por fixação biológica do N2 (FBN). Essa publicação é um marco por associar o benefício da FBN à produção sustentável de bioenergia, embora seja apenas um exemplo da contribuição do grupo de pesquisadores da Embrapa Agrobiologia para o estudo de FBN em gramíneas e na cana-de-açúcar em particular. 
Os estudos nessa área tiveram início bem antes, quando Johanna Döbereiner, que formou e liderou o grupo de FBN da Embrapa, isolou, em 1961, bactérias fixadoras de nitrogênio em cana. Desde então, pesquisadores como Alaídes P. Rushel, Eduardo Lima, Verônica Reis, José Ivo Baldani, Vera L. Baldani, Segundo Urquiaga, Bruno Alves, o próprio Robert M. Boddey, entre outros, vêm avançando as pesquisas em FBN, e muitos organismos já foram identificados. Um inoculante chegou a ser produzido para reduzir a dependência da cana de fertilizantes nitrogenados, mas ainda há desafios a vencer para que isso se torne uma realidade em condições de campo.

No Centro de Energia Nuclear na Agricultura da USP (CENA/USP) foram importantes também os trabalhos de Siu M. Tsai na área de fixação biológica de nitrogênio e função dos micro-organismos no ciclo do nitrogênio.

\section{Avanços em manejo e adubação de cana-de-açúcar}

Os enormes progressos observados na produtividade da cana-de-açúcar são fruto do trabalho de melhoramento (já mencionado neste livro), mas também dos desenvolvimentos em manejo da cultura, nutrição e adubação, controle de pragas e doenças, mecanização agrícola etc, que permitiram a expansão dessa cultura dos melhores solos onde era cultivada, principalmente em São Paulo, para solos com limitada fertilidade e condições climáticas mais desafiadoras. Os ganhos incrementais ao longo dos anos no manejo agrícola, obtidos com a ajuda de muitos, colaborou decisivamente para a melhoria dos indicadores dessa cultura. Como esses desenvolvimentos são regionais, há um grande grupo de pesquisadores que contribuíram decisivamente nas áreas de adubação e nutrição de cana: José L. I. Demattê, Nadir Almeida da Glória, Jairo Mazza, Waldomiro Bittencourt, Godofredo Vitti, Euripedes Malavolta e Edgard de Beauclair (ESALQ/USP), Paulo Trivelin (CENA/USP), o grupo do CTC, incluindo Claudimir Penatti e Pedro Donzelli, pesquisadores do antigo Planalsucar: José Orlando Filho, Rubismar Stolf, o grupo do IAC que publicou as recomendações de adubação para cana em 1996 (Ademar Espironello, Bernardo van Raij, Heitor Cantarella, Raffaella Rossetto, José Antonio Quaggio, e outros que ingressaram posteriormente no grupo da APTA, como André Vitti e Glauber Gava). Da UFU, Gaspar Korndorfer; da Unesp, Carlos Crusciol, Ailton Casagrande e Miguel Mutton. Muitos técnicos da iniciativa privada, em parceria com o setor acadêmico, ajudaram a avançar os estudos em manejo e adubação, como Jorge Morelli e Tadeu Coletti. Trabalhos pioneiros foram desenvolvidos no Nordeste por Elias Sultanu e Murilo Marinho. Uma nova geração de pesquisadores continua esse trabalho e será reconhecida em edições futuras. 
Nas áreas de fisiologia e biotecnologia da cana-de-açúcar tiveram grande contribuição: Paulo R. Castro e Otto Crocomo, da ESALQ/USP. Entre os nomes importantes nos estudos de pragas estão: Newton Macedo (Planalsucar), Wilson R. T. Novaretti (CTC), Arthur Mendonça (Planalsucar-NE), Paulo Botelho (UFSCar) e José Roberto Postali Parra (ESALQ) ${ }^{12}$. As pesquisas com doenças de cana-de-açúcar tiveram contribuições de: Álvaro Sanguino (CTC), Pery Figueiredo (IB), Sizuo Matsuoka (UFSCar), Lee S. Tseng (UFSCar) e Hasime Tokeshi (ESALQ). Na área de mecanização agrícola alguns dos nomes a serem citados são: Caetano Rípoli, Luis G. Mialhe, José Paulo Molin (ESALQ), José Fernandes (Planalsucar), Vitorio L. Furlani (UFSCar) e Oscar Braunbeck (FEAGRI/Unicamp e posteriormente CTBE).

\section{A contribuição da pesquisa desenvolvida pelas empresas}

Também a indústria brasileira realizou pesquisas importantes em etanol de cana. Destacam-se: a integração da Dedini das produções de etanol e biodiesel, o desenvolvimento do processo "organosolv" de hidrólise de bagaço, conhecido como Dedini Hidrólise Rápida (DHR), biodigestão de vinhaça da Codistil-Dedini, projeto Biostil, da Alfa-Laval, o Bagatex, para compactação de bagaço e, mais recentemente, o desenvolvimento de um processo para redução da quantidade de vinhaça pela Fermentec, com planta de demonstração, desenvolvida e construída pela Dedini e implantada na Usina Bom Retiro, conforme visto anteriormente.

Sobre o projeto Dedini Hidrólise Rápida, que utilizou recursos financeiros do Banco Mundial aportados por meio da Secretaria de Tecnologia Industrial (STI), do Ministério de Indústria e do Comércio (MIC), e cofinanciado pela Fapesp, pode-se dizer que foi pioneiro no desenvolvimento do processo de hidrólise de bagaço, introduzindo o conceito de integração da primeira geração com a segunda geração. Tratou-se de um desenvolvimento em laboratório em 1984 e piloto de processo de pré-tratamento organosolv (etanol/ água) em reator contínuo à pressão de aproximadamente 20 bar e $200{ }^{\circ} \mathrm{C}$, em 1989 . Na época do projeto não se dispunha de uma tecnologia de hidrólise enzimática madura, e o pré-tratamento organosolv foi integrado com a hidrólise ácida. A instalação foi desenvolvida sob projeto de engenharia e fabricação de equipamentos pela indústria brasileira. Isso representou um marco no desenvolvimento da hidrólise e tratou-se de desenvolvimento de tecnologia genuinamente brasileira.

12 Ver também a seção sobre controle biológico de pragas da cana-de-açúcar, neste capítulo. 
A planta-piloto tinha capacidade de cem litros de etanol por dia e continha todos os processos unitários necessários para a produção do etanol a partir do bagaço de cana, tendo sido construída nos moldes de uma planta industrial, contínua e totalmente instrumentada com controle de processo (Figura 36). A planta operou até meados da década de 1990 como um projeto exclusivo da Dedini, quando então se decidiu pela busca de uma parceria para completar o desenvolvimento.

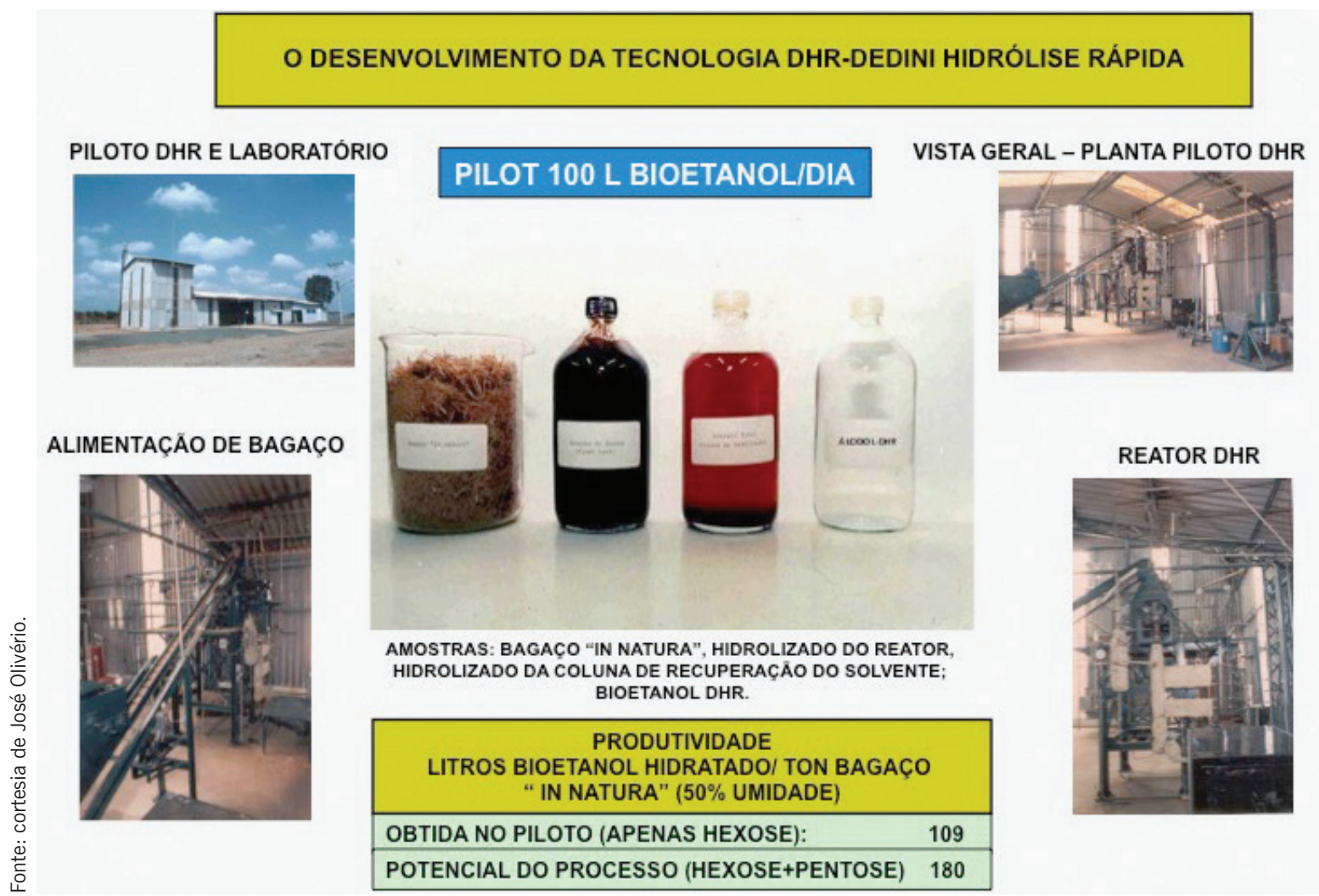

Figura 36: A planta-piloto DHR $100 \mathrm{~L} /$ dia e os rendimentos obtidos.

As pesquisas com produção de etanol celulósico voltaram a acontecer no final da década de 1990, quando a Dedini, em parceria com o CTC e com o financiamento da Fapesp, voltou a realizar estudos nessa área, coordenados por Carlos Vaz Rossell, que apresentou um inovador paper sobre a fermentação do 
hidrolisado (Rossell et al., 2005) no XXV Congresso da International Society of Sugar Cane Technologists (ISSCT), na Guatemala, trabalho que recebeu o prêmio Best Paper na seção de coprodutos. A tecnologia organosolv de pré-tratamento de bagaço (Figura 37) foi usada em uma nova planta-piloto de maior dimensão, instalada na Usina São Luiz, em Pirassununga (SP), que iniciou a operação em 2003 (Olivério; Hilst, 2005). A planta tinha capacidade de produzir 5 mil litros de etanol/dia e operou até 2008. Embora esse projeto tivesse sido concebido com mais certeza de sucesso, dado que aproveitaria a sinergia de um processo integrado à primeira geração, problemas técnicos, principalmente a abrasão em tubulações, válvulas e bombas impedindo a continuidade da operação da planta por longos períodos, bem como por outras questões, comprometeram o seu sucesso.

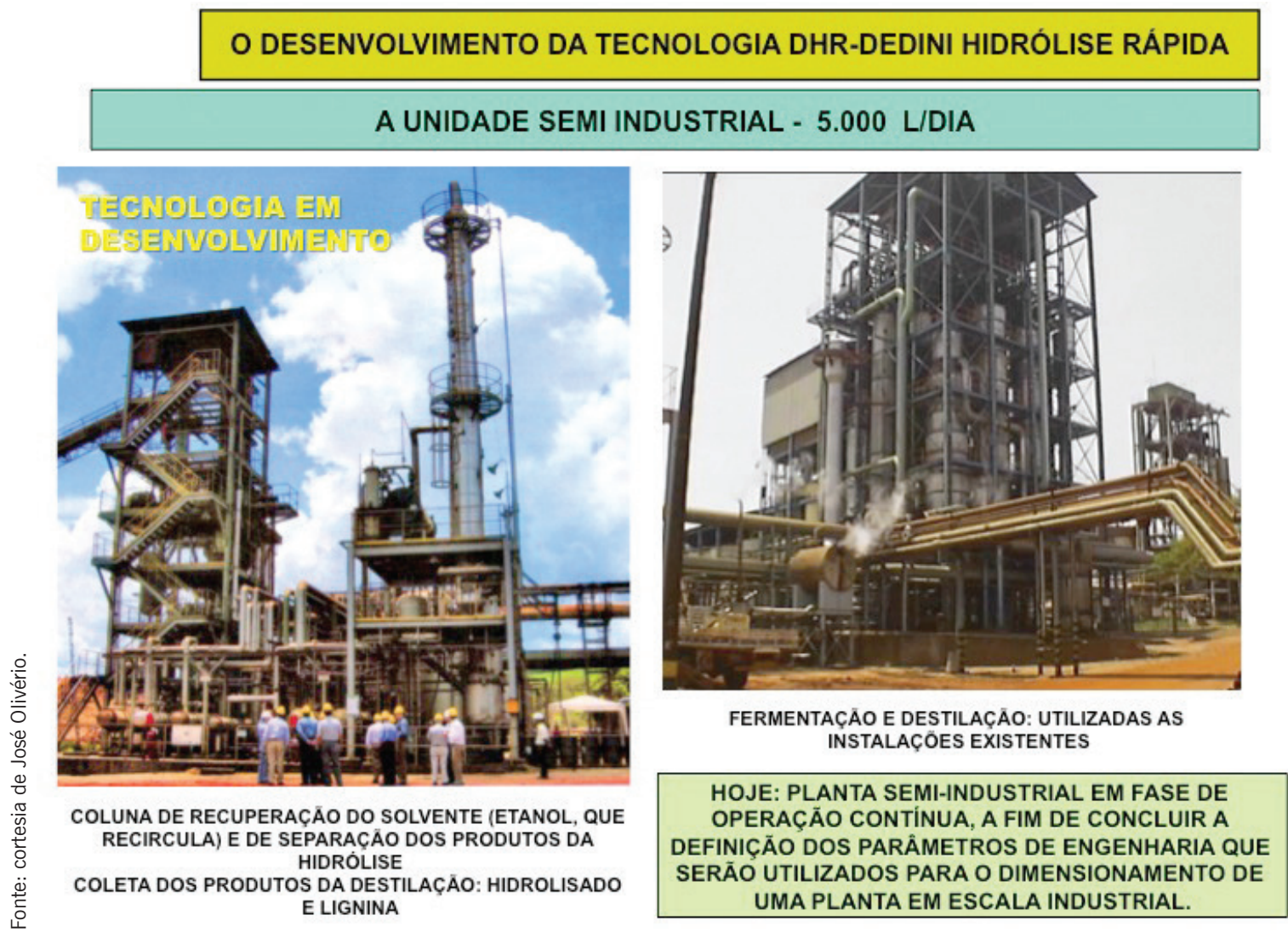

Figura 37: A Planta DHR de desenvolvimento de processo $5 \mathrm{mil} \mathrm{L/dia.}$ 
A Fapesp organizou, em 3 de julho de 2008, um seminário sobre projetos em andamento que contaram com o seu aporte de recursos, no qual a evolução/desenvolvimento do DHR foi apresentada com mais detalhes.

Vale ressaltar ainda um importante esforço da Dedini para desenvolver soluções ambientalmente mais sustentáveis, no sentido de reduzir o uso de água no processo de produção do etanol, assim como na reciclagem dos resíduos sólidos e líquidos a serem utilizados como adubo. Vários desses projetos contaram com a participação de técnicos do Centro de Tecnologia Canavieira (CTC).

Todas essas contribuições podem ser apreciadas no projeto denominado Usina Sustentável Dedini (USD), apresentado ao setor sucroenergético em 2009, no Ethanol Summit 2009 (Olivério, 2009a) e posteriormente apresentado e publicado no XXVII Congresso Internacional do ISSCT (Olivério et al., 2010b).

A USD é definida por José Luiz Olivério como uma “macromáquina”, projetada para atender os critérios de maximização da sustentabilidade. Com esse objetivo, foram integradas tecnologias existentes, introduzidas inovações, desenvolvidos novosprocessoseprocuradassinergiasparaumanova concepçãodeusina, voltadaà sustentabilidade.

Ao final, a USD produz seis bioprodutos: bioaçúcar, bioetanol, bioeletricidade, biodiesel, biofertilizante e bioágua, em um projeto integrado objetivando minimizar a emissão e maximizar a mitigação de gases de efeito estufa (GEE). A USD pode ser implementada em partes, como é o caso da Usina Barralcool, em Barra dos Bugres (MT), que, desde 2006, produz os primeiros quatro "bios" da relação acima, com o fornecimento pela Dedini de uma planta de biodiesel integrada pioneiramente a uma usina canavieira.

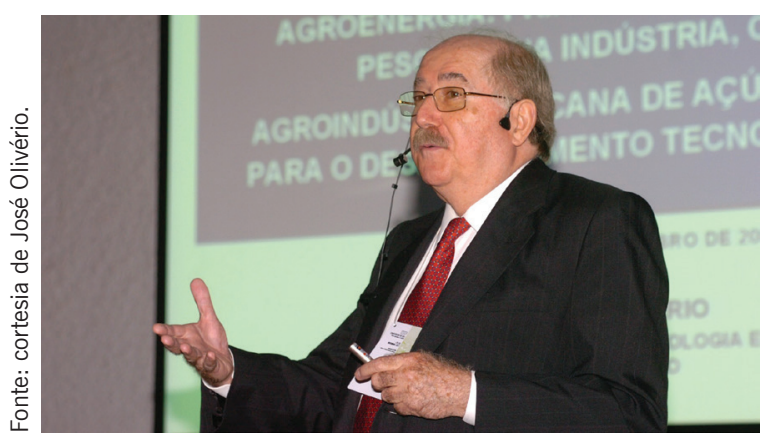

Figura 38: José Luiz Olivério (Dedini).

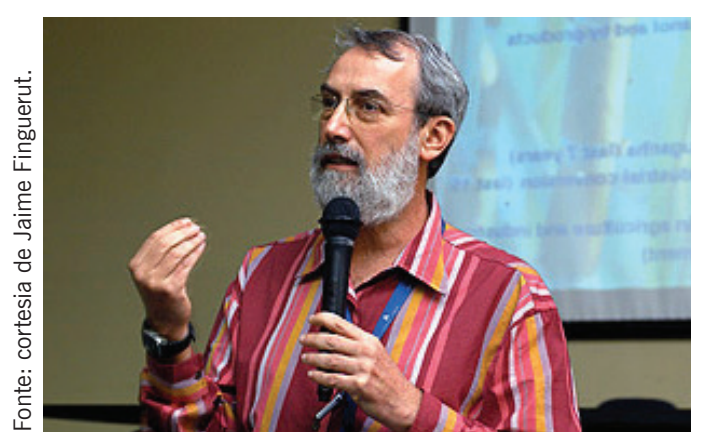

Figura 39: Jaime Finguerut (CTC). 
A USD foi concebida e projetada atendendo ao trinômio economia + sociedade + meio ambiente e atende a dois conceitos básicos:

\section{Conceito "otimização":}

- máximo bioaçúcar;

- máximo bioetanol;

- máxima bioeletricidade;

- biodiesel integrado;

- máximo efeito de mitigação de GEE.

\section{Conceito "zero":}

- zero resíduos;

- zero efluentes líquidos;

- zero odores;

- zero água de mananciais;

- mínimas emissões.

Na comparação da USD com uma usina tradicional, segundo Olivério (2014), destacam-se os seguintes pontos:

- Otimiza os processos de produção, possibilitando máxima produção de bioaçúcar e bioetanol por tonelada de cana. Dessa forma, maior quantidade de etanol estará disponível para substituir a gasolina, evitando ainda mais emissões de GEE.

- Otimiza o projeto energético da usina, produzindo o máximo de bioeletricidade, inclusive pelo uso da palha, evitando o uso de combustível fóssil e evitando ainda mais emissões de GEE.

- Inclui a produção de biodiesel integrado à usina, com integração agrícola pela lavoura de soja em rotação com a cana e integração industrial energética e de processos ao usar o etanol como segunda matéria prima, possibilitando produzir o biodiesel etílico 100\% "verde" que é utilizado na própria frota da lavoura e para venda a terceiros, evitando o uso do diesel e também as emissões de GEE.

- Todos os resíduos do processo (vinhaça concentrada, torta de filtro, cinza e fuligem das caldeiras) são utilizados para produzir o biofertilizante organomineral (Biofom), que substitui cerca de $70 \%$ dos fertilizante químicos, evitando emissões de GEE (Figura 40).

- A usina fica autossuficiente em água, somente utilizando e reciclando a água contida na cana e sem demandar água de mananciais, gerando inclusive excedente a ser exportado (a bioágua). Ressalte-se que uma usina típica consome 23 litros de água de mananciais por litro de etanol produzido, enquanto a USD exporta 3,7 litros de água por litro de etanol (Olivério, 2011b).

- A USD incorpora os mais avançados conceitos de higiene e segurança do trabalho. 
- O bioetanol produzido pela USD tem um efeito mitigador de GEE de $112 \%$ (e 132\% utilizando 50\% da palha como energético), enquanto o etanol produzido pela usina tradicional possui $89 \%$ de mitigação (Figura 41).

Ao final, a USD resulta da integração de várias tecnologias sob o foco da sustentabilidade, com inovações desenvolvidas pela própria Dedini e/ou parceiros, gerando dez pedidos de patentes.
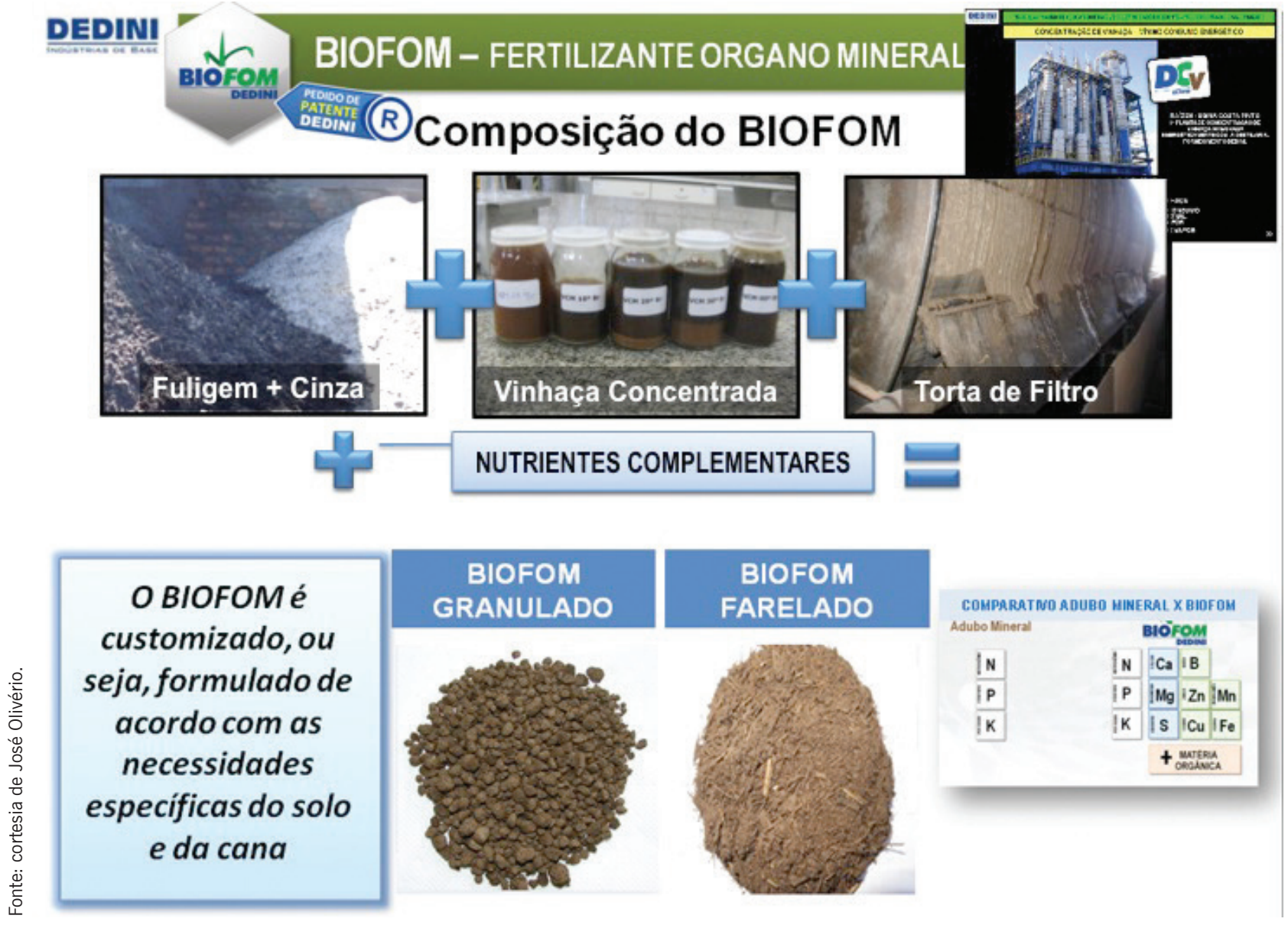

Figura 40: 0 Biofom (biofertilizante organomineral). 


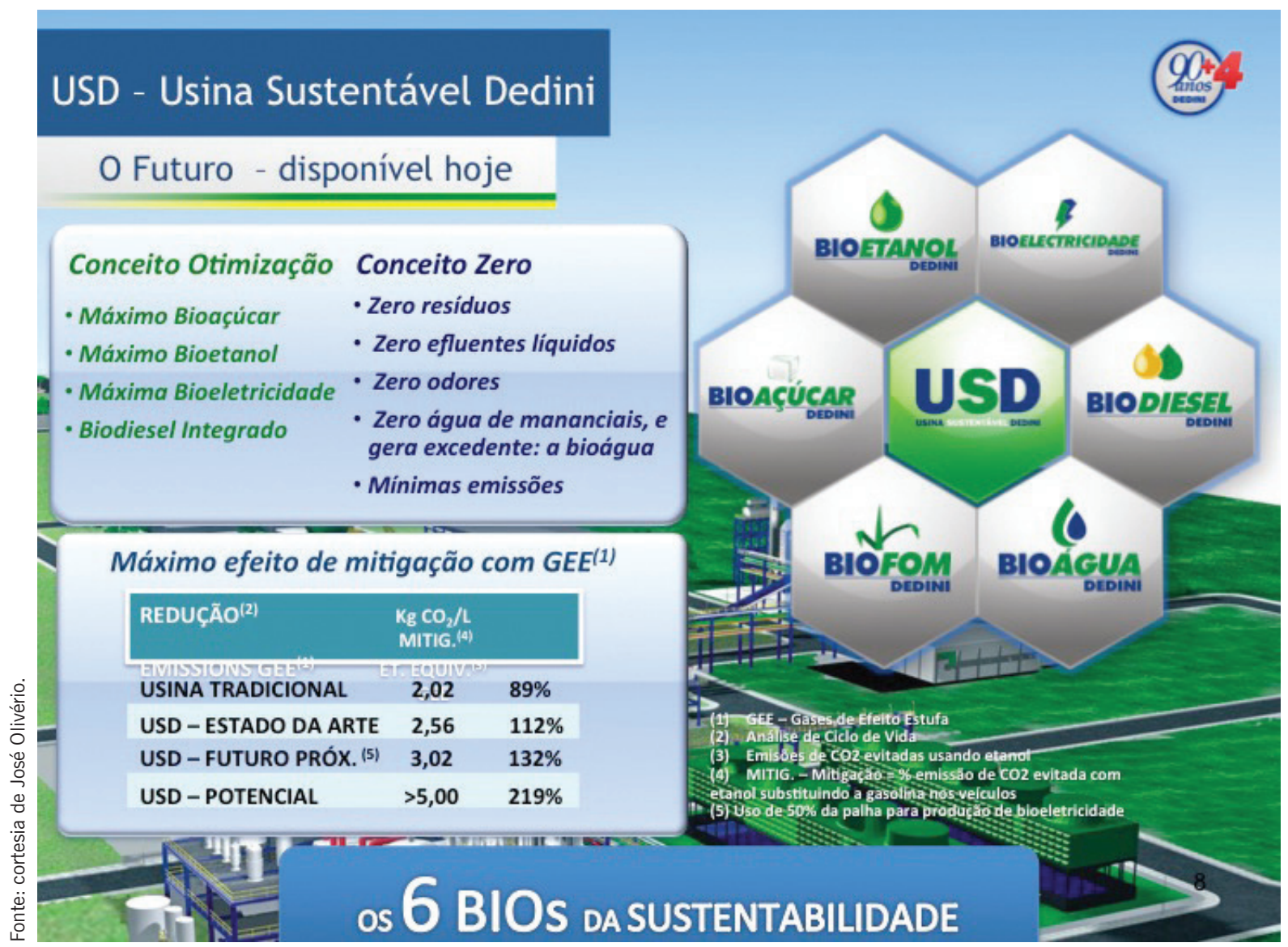

Figura 41: Usina Sustentável Dedini (USD, a usina 6 Bios).

A USD recebeu dois prêmios nacionais e reconhecimento internacional ao ser convidada para ser apresentada na seção plenária do XXVII Congresso Internacional do ISSCT, em Vera Cruz, no México (Olivério, 2010b).

Assim, o etanol da USD é um verdadeiro "bioetanol premium", possibilitando maiores ganhos em "créditos de carbono". 


\section{A pirólise rápida chega à cana}

No campo das pesquisas em carvoejamento e pirólise, vale mencionar os trabalhos realizados na UFMG por Maria Emília Rezende, que resultaram na criação da empresa Biocarbo, embora esta não tenha chegado a atuar em biomassa de cana-de-açúcar. Já na região de Campinas, como resultado dos esforços de Saul D’Ávila e Themístocles Rocha, surgiu a empresa Termoquip, que produzia gaseificadores de biomassa, inclusive para a Petrobras, permitindo a criação de vários gaseificadores usados para pesquisas na Unicamp e Unifei. Também vale ser citada a empresa Bioware utilizando tecnologia de pirólise de subprodutos da cana-de-açúcar para produção de bio-óleo, carvão e ácidos pirolíticos.

\section{Década de 1990: o projeto Global Environment Facility (GEF) do CTC}

Já o CTC conduziu o projeto GEF - Fase 1 na década de 1990, com o apoio do Banco Mundial, para realizar pesquisas em recolhimento de palha e gaseificação de palha e bagaço. Esse projeto visava alcançar a construção de uma planta-piloto de gaseificação avançada, mas problemas de financiamento, naquela época, comprometeram o sucesso da iniciativa. A Companhia Hidro Elétrica do São Francisco (CHESF) tentou realizar a segunda fase com um enfoque de gaseificação de madeira de eucalipto, tendo inclusive financiamento de 50 milhões de dólares do Banco Mundial, CTC e CHESF. Esses dois insucessos no assentamento de uma planta de demonstração de geração de energia elétrica a partir de gaseificação avançada de biomassa causaram desestímulo na época.

\section{6: criação do Cenbio}

Em 1996, cria-se na USP, por iniciativa do Ministério da Ciência, Tecnologia e Inovação (MCT), da Secretaria de Energia do Estado de São Paulo e da ONG Biomass Users Network do Brasil, o Centro Nacional de Referência em Biomassa (Cenbio) (Figura 42).

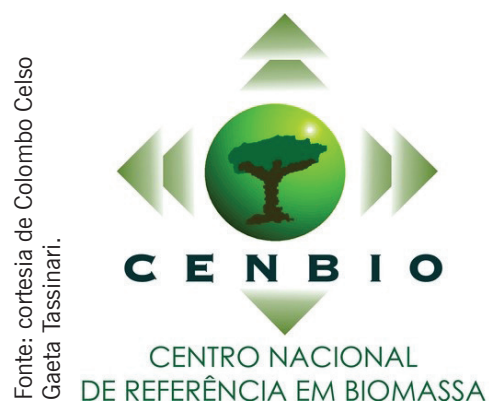

Figura 42: Cenbio. 
O Cenbio tem por objetivo desenvolver atividades de pesquisa em forma de rede com universidades e empresas para a promoção do uso moderno de biomassa. Desde sua criação, por meio do Cenbio têm-se realizado importantes contribuições às políticas governamentais no âmbito estadual, como os estudos da Comissão Especial de Bioenergia do Estado de São Paulo, coordenados por José Goldemberg (Goldemberg, Nigro e Coelho, 2008), e no âmbito federal, como a instalação de unidades de geração de eletricidade da biomassa em comunidades da Amazônia e a aprovação de um projeto de captura e armazenagem do $\mathrm{CO}_{2}$ da fermentação do caldo de cana em etanol pelo Global Environment Facility e MCT, em 2010. Essas ações foram realizadas dentro do Cenbio em conjunto com Suani Coelho (Figura 44) e José Roberto Moreira, do Biomass Users Network (BUN). Em 2015, o Cenbio teve seu nome substituído por Grupo de Pesquisa em Bioenergia, do Instituto de Energia e Ambiente da USP (IEE/USP).

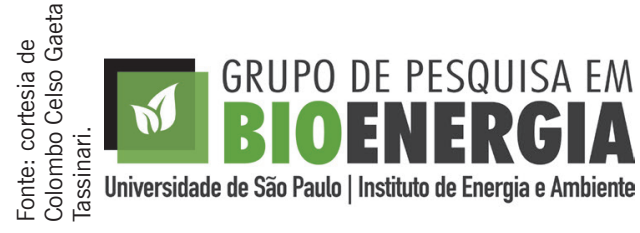

Figura 43: Grupo de pesquisa em bioenergia do IEE/USP.

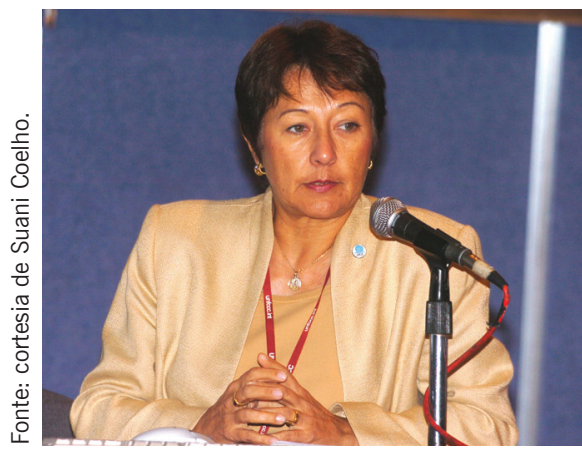

Figura 44: Suani Coelho.

\section{7: retomada das pesquisas do IPT sobre utilização de etanol}

Em decorrência do envelhecimento e sucateamento da frota de veículos a álcool no país, vinha ocorrendo uma redução da demanda por etanol hidratado. A combinação dessa situação com uma queda do preço do açúcar e aumento do preço do petróleo nos mercados internacionais provocou uma retomada das pesquisas e testes sobre novas aplicações de etanol como combustível. Dessa maneira, novos projetos e testes passaram a ser demandados pelo setor privado ao Laboratório de Motores do IPT, como:

- 1997/1998, Unica: Uso de emulsões de etanol hidratado em óleo diesel para aplicação em motores diesel - ensaios de desempenho e emissões e testes de campo em frota de ônibus.

- 1998, Alcopar: Uso de misturas etanol anidro/diesel em motores: ensaios de desempenho e emissões em dinamômetro.

- 1999, IPT: Estudos sobre o estado da arte e testes preliminares com veículos flexíveis. 
- No mesmo período a divisão de química desenvolvia projetos de pesquisa sobre produção de plástico biodegradável e hidrólise de bagaço.

- Abril de 2000: Realização de seminário sobre motores flexíveis no IPT, antecipando e provocando o início da corrida pela tecnologia flexível no país.

Vale mencionar que, embora os sistemistas fossem favoráveis à introdução da tecnologia, a Anfavea manifestava-se contrária ao veículo flex, apelidando-o de "carro pato" (anda, nada e voa, mas faz tudo malfeito) e os produtores de etanol também decidiram se pronunciar contrários ao uso da tecnologia flexível na semana anterior ao seminário. Mesmo assim, com trabalhos técnicos consistentes sendo apresentados pelo IPT, por um representante da Unica, por sistemistas e por uma montadora, e contando com grande participação de representantes do governo do estado e federal e com a divulgação na mídia televisiva de modelos flexíveis sendo abastecidos, o seminário surtiu o efeito esperado na motivação dos consumidores de novos veículos. Assim, após o marketing de montadoras ter identificado forte demanda por esse tipo de tecnologia que já estava sendo ofertada pelos sistemistas, e decorridos três anos da realização do seminário, foi lançado o primeiro veículo flexível no país, configurando plenamente a tecnologia flex como uma inovação de mercado (Nascimento et al., 2009).

Segundo Francisco Nigro (2012), do IPT e da Escola Politécnica (Figura 45), foram muitas as lições aprendidas nessas décadas de pesquisas com etanol. Entre elas:

- A escala de tempo de desenvolvimento de programas de energia alternativa é a dezena de anos.

- É fundamental possuir, antecipadamente, a visão estratégica global do empreendimento, inclusive dos papéis a serem desempenhados por cada ator importante: área de ciência e tecnologia (C\&T), governos, sociedade (setores econômicos já estabelecidos, empreendedores,

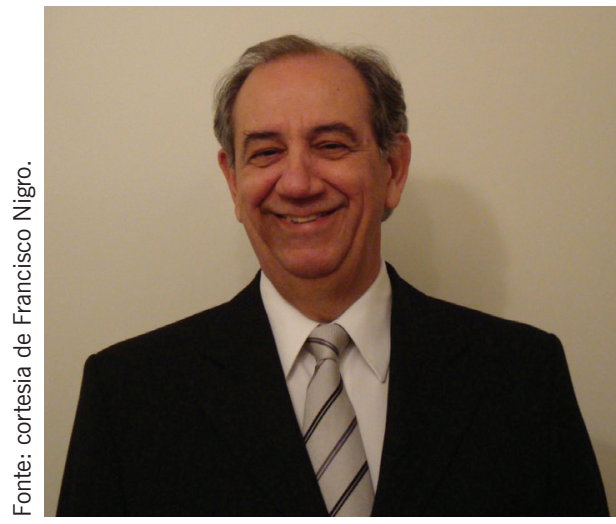

Figura 45: Francisco Nigro. consumidores finais etc.).

- A atração de multinacionais globais para atuarem na solução de problemas locais pode ser conseguida acenando-se com a demanda pelos consumidores. 
- Um papel fundamental das entidades públicas de C\&T deve ser mostrar o caminho, ainda que raramente possam se beneficiar economicamente do movimento provocado.

- Além da dedicação aos vários aspectos materiais da visão estratégica: infraestrutura física, sustentabilidade econômica, social e ambiental etc., destinar esforço especial à divulgação da visão e mobilização dos consumidores finais.

\section{9: aferindo a qualidade do etanol combustivel}

Em 1999, o primeiro fundo setorial da Finep (CT-PETRO), juntamente com o CNPq, propiciou a instalação de Laboratórios de Monitoramento da Qualidade do etanol (e outros combustíveis) em diversas universidades brasileiras, visando garantir a qualidade desse biocombustível em todo o território nacional, ficando a licitação e fiscalização desses laboratórios sob a responsabilidade da ANP.

A evolução da qualidade do etanol anidro e hidratado, produzido durante os quarenta anos do Programa Proácool, pode ser aferida pelas alterações ocorridas nas especificações técnicas exigidas para esse produto. Assim, limites máximos permitidos de concentração de alguns contaminantes foram modificados, enquanto outros contaminantes passaram a integrar as especificações técnicas desse produto (Normas Técnicas da Agência Nacional do Petróleo).

A qualidade do produto também tem desempenhado um papel preponderante na sustentabilidade econômica do etanol anidro como aditivo da gasolina, uma vez que a qualidade esteve presente na harmonização das especificações desse produto, realizada em 2007, visando à transformação do etanol em uma commodity global (White Paper - European Committee for Standardization (CEN), U.S. National Institute of Standards and Technology (NIST) e o Instituto Nacional de Metrologia (Inmetro), 2007).

Outra importante contribuição foi a invenção do densímetro termocompensado usado em vários postos de revenda, por Luís Antonio Pinto, que doou a patente para o Conselho Nacional do Petróleo (CNP) com o intuito de contribuir para a disseminação do uso do etanol combustível e sua aceitação pelo mercado consumidor ${ }^{13}$.

13 Informação prestada por Plínio Nastari. 


\section{Antecedentes do carro flex}

A década de 1990 foi marcada por uma reestruturação do setor sucroalcooleiro por meio da desregulamentação paulatina, ao mesmo tempo que uma redução na demanda de etanol forçou os produtores a encaminhar mais cana para a produção de açúcar. Devido a isso, o produto passou a ganhar mercados no exterior, fazendo o Brasil se tornar um grande exportador de açúcar. Já a indústria automobilística, com a saída do carro a álcool do mercado, começou a observar as mudanças no mercado de combustíveis para veículos leves no país.

O álcool consumido internamente passaria a ser mais anidro que hidratado, mantendo-se mais ou menos constante a soma de ambos. Já no final da década de 1990, devido à queda no preço do etanol hidratado, muitos consumidores de gasolina (E20/E25) ${ }^{14}$ passaram a utilizar em seus motores quantidades adicionais de etanol hidratado, formando misturas conhecidas popularmente como "rabo de galo".

Essa prática levou algumas montadoras a considerarem a introdução de carros flex $^{15}$, isto é, com motores capazes de funcionar com quaisquer misturas gasolina-etanol (variando de E20 a E25 ${ }^{16}$ ). No entanto, foi a empresa Magnetti Marelli que desenvolveu tecnologias para baixar o custo de produção dos sensores.

É importante que se mencione também que a introdução da tecnologia flex-fuel permitiu ampliar significativamente o mercado interno de etanol no Brasil, como destaca Eduardo Carvalho, ex-presidente da Unica. O aumento da venda de carros flex-fuel fez a produção de cana-de-açúcar e de etanol mudar de patamar, sendo por esta razão responsável pelas elevadas taxas de crescimento do setor sucroalcooleiro experimentadas na primeira década do século XXI, pelo menos até $2008^{17}$.

Paralelamente, já no governo Fernando Henrique Cardoso, se deu a reestruturação do setor energético com a criação das agências reguladoras: ANEEL para o setor elétrico e ANP para o petróleo e combustíveis em geral. Com a Lei n. 9.478, terminava também o monopólio da Petrobras sobre a exploração

14 E20 refere-se ao combustível que contém 20\% de etanol e E25 à 25\%, respectivamente.

15 Os veículos flex foram introduzidos a partir de 2003. Até então havia veículos à gasolina (contendo até $25 \%$ de etanol) e veículos a etanol ( $96 \%$ etanol, $4 \%$ água v/v). Hoje, o nível de etanol na mistura com gasolina é de $27 \%$.

16 De 20\% a 25\% de Álcool Etílico Anidro Combustível (AEAC), segundo especificação da ANP.

17 Mais informações sobre a tecnologia flex-fuel e a sua importância para a indústria podem ser encontradas em Teixeira (2005). 
de petróleo no país. Com essa lei, um novo período promissor abriu-se para o setor de petróleo no país, viabilizando o aumento da produção de petróleo e gás.

A ANP foi criada também pela Lei n. 9.478 como Agência Nacional do Petróleo. Esta só passou a ser chamada de Agência Nacional do Petróleo, Gás Natural e Biocombustíveis a partir de 2011, por meio da Lei n. 12.490, que incluiu o etanol entre os produtos cuja produção, distribuição e comercialização são reguladas pela ANP. Já, o pré-sal ${ }^{18}$ foi instituído em regime de partilha pela Lei n. 12.351 de 2010.

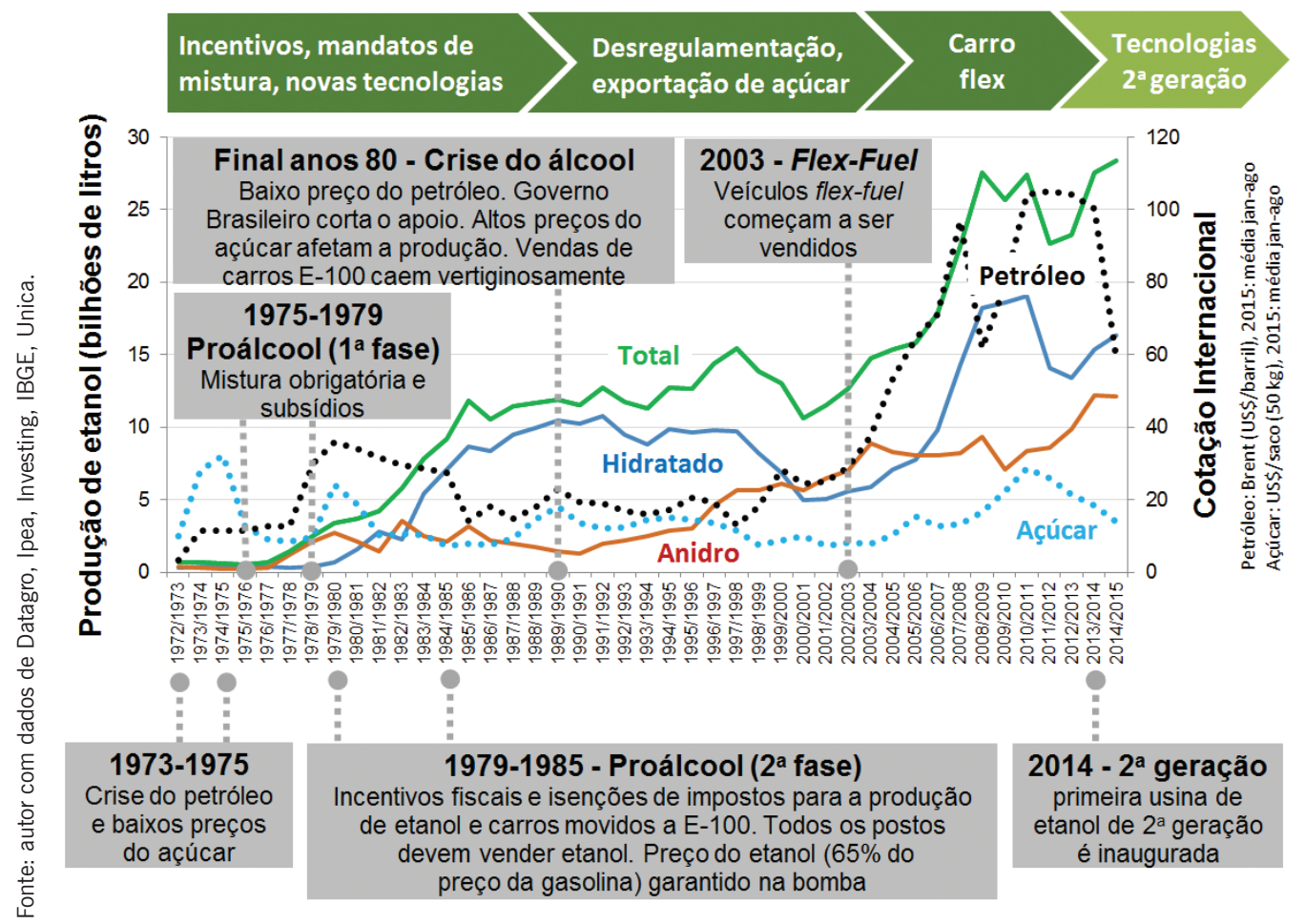

Figura 46: Fases do Proálcool 1972-2015.

18 A camada pré-sal é um grande reservatório de petróleo e gás natural, caracterizada por estar entre 4 mil e 5 mil metros de profundidade, abaixo do fundo do mar, localizada nas bacias de Santos, Campos e Espírito Santo, na região litorânea entre os estados de Santa Catarina e Espírito Santo. As estimativas de volumes variam de 8 bilhões a 80 bilhões de barris de petróleo. 
Na segunda metade da década de 1990, o governo federal criou os fundos setoriais. O CTEnerg foi concebido para estimular a pesquisa e a inovação em energia no Brasil, tratando de todos os aspectos técnicos da energia exceto o petróleo, que recebeu um fundo específico, o CTPetro.

Nesse sentido, o CTEnerg passou a ser considerado uma ferramenta muito criativa para promover a investigação orientada, ainda que o foco não fosse propriamente a bioenergia. Outros mecanismos foram criados para financiar a pesquisa setorial na mesma época em que o país vivia um processo de privatização - foram os de "P\&D" e "Eficiência Energética" -, coordenados pela ANEEL e ANP em conjunto com as concessionárias de energia.

\section{Criação pela Fapesp do Projeto Genoma}

\section{A Fundação de Amparo à Pesquisa do Estado de} São Paulo (Fapesp), financiada com 1\% do ICMS do estado de São Paulo, tem igualmente aplicado desde cedo consideráveis recursos em bioenergia. Em 1998, o projeto SucEST, financiado pela Fapesp como parte do seu Programa Genoma, iniciou o sequenciamento dos marcadores de sequências genéticas (ESTs) da cana-de-açúcar.

O genoma gigante de cana-de-açúcar, no qual um gene é em média representado por dez alelos, é um dos grandes desafios atuais de sequenciamento. Coleções de ESTs representam a alternativa mais rápida para uma caracterização inicial das sequências expressas, podendo contribuir significativamente para a identificação de genes associados a características agronômicas de interesse.

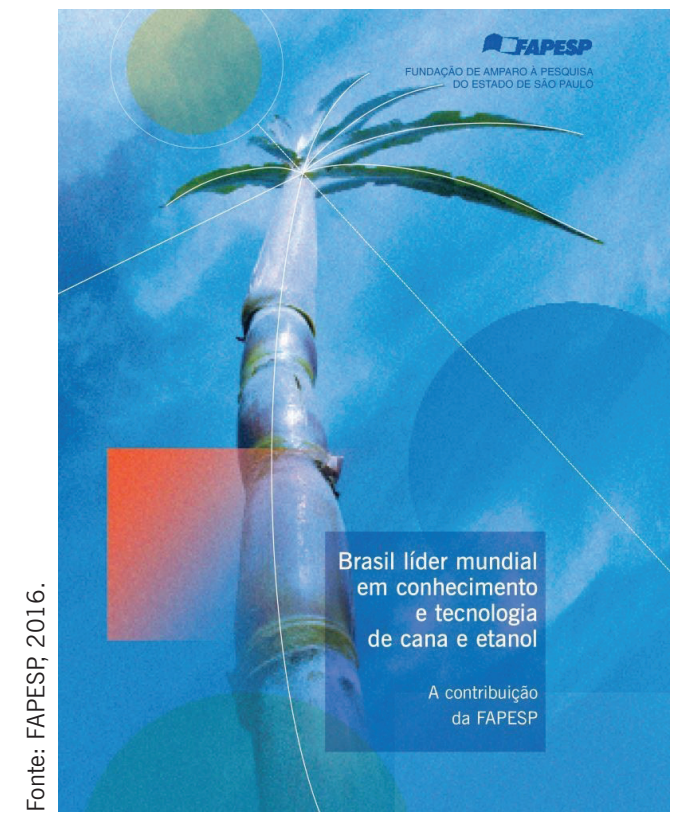

Figura 47: Brasil líder mundial em conhecimento e tecnologia de cana e etanol, uma publicação da Fapesp. 
Cerca de 43 mil genes transcritos foram identificados no SucEST (Vettore et al., 2003). Essa iniciativa foi fundamental na formação de uma rede de pesquisa em genômica no Brasil e colocou o país na liderança em publicações internacionais indexadas sobre a cana. Um levantamento das pesquisas em cana e etanol, financiadas pela Fapesp naqueles anos, foi publicado em Brasil líder mundial em conhecimento e tecnologia de cana etanol, em português e inglês (Figura 47). Uma demonstração do impacto da entrada da Fapesp no financiamento à pesquisa, na área de cana-de-açúcar, pode ser vista na Figura 48.

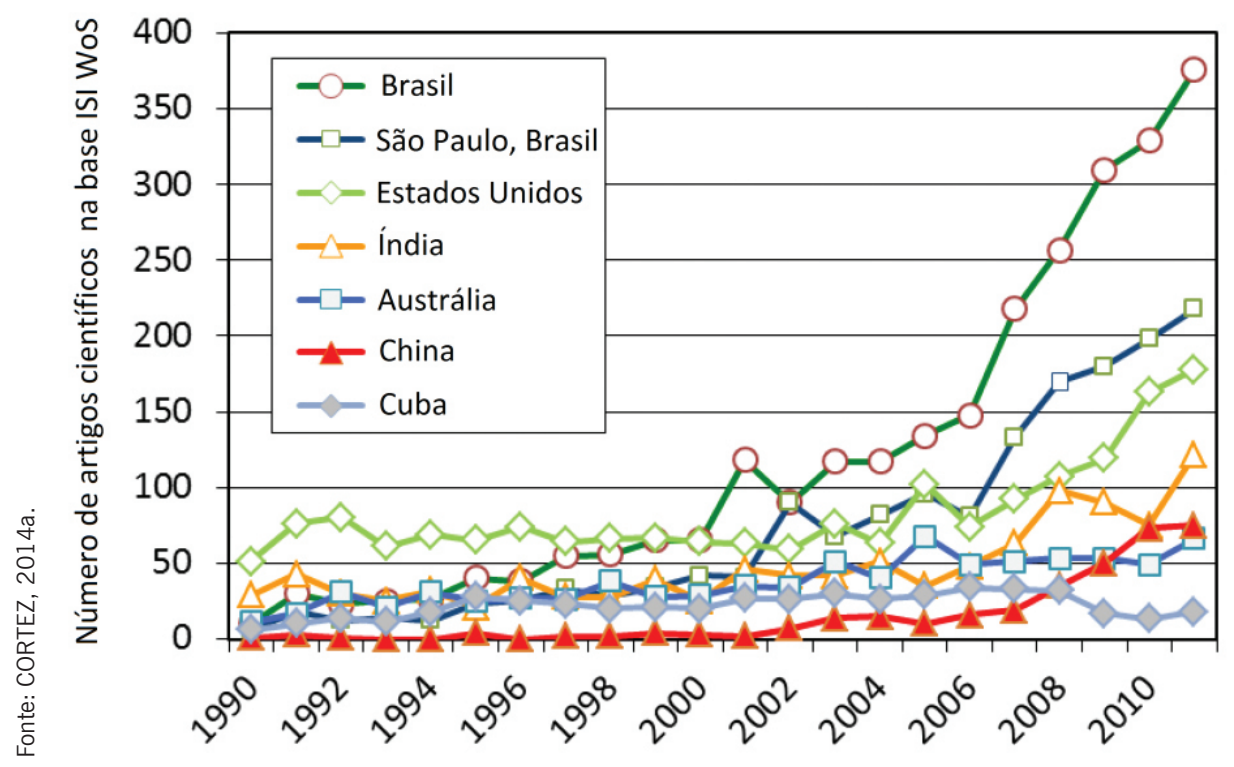

Figura 48: Evolução do número dos artigos científicos citados no ISI WoS em cana-de-açúcar comparado aos principais países produtores de açúcar.

Em 2003, o SucEST-FUN ${ }^{19}$ foi criado para identificar a função dos genes. E, desde 2012, o BIOEN se dedica a montar o genoma poliploide gigante da planta, usando várias tecnologias de sequenciamento de última geração, em parceria com a Microsoft.

19 Ver $<$ http://sucest-fun.org $>$. 
Foram identificados genes de cultivares comerciais e dos ancestrais da cana, avançando o nosso conhecimento para o desenvolvimento de plataformas genômicas de melhoramento.

A Alellyx foi uma empresa fundada em fevereiro de 2002 por um grupo de biólogos moleculares e bioinformáticos, incluindo Paulo Arruda, da Unicamp, envolvidos no Projeto SucEST ou que participaram do Programa Genoma Fapesp. Instalada em Campinas, a Alellyx atuou em parceria com a empresa CanaVialis, fundada em 2003 e cujo foco era o melhoramento genético da cana-de-açúcar. Juntas, Allelyx e CanaVialis representaram um dos mais modernos programas de melhoramento de cana do mundo e um importante resultado do Programa Genoma Fapesp. Ambas as empresas foram adquiridas pela Monsanto, mas recentemente desativadas. Como dito anteriormente, em outubro de 2015, a Monsanto encerrou as atividades nessa área.

\section{Pagamento da cana pela qualidade}

No final da década de $1990^{20}$, a Organização dos Plantadores de Cana da Região Centro-Sul do Brasil (Orplana) e membros da Unica constituíram um grupo técnico com o objetivo de elaborar um modelo de autogestão, com regras de relacionamento e um sistema de remuneração da matéria-prima.

Até então a cana que chegava à usina era paga aos fornecedores considerando apenas o seu peso. Necessitava-se de um novo modelo que considerasse também o teor de açúcar (pol) da cana, além do peso. A partir daí esse grupo técnico criou e implantou um sistema de pagamento da cana pela qualidade no país (no estado de São Paulo e outros estados que aderiram), sistema que representou um significativo avanço na tecnologia do setor.

Esse novo modelo ficou conhecido como Consecana (Conselho dos Produtores de Cana-de-açúcar, Açúcar e Álcool do Estado de São Paulo), e foi implantado na safra de 1998/1999, tornando-se referência para a remuneração da cana.

20 O modelo de pagamento por sacarose já vinha sendo estudado desde 1978, segundo Manoel Ortolan, da Orplana. 


\section{Anos 2000}

\section{Fim das queimadas de cana-de-açúcar}

As queimadas de cana, que antecedem a colheita, eram consideradas um grande problema ambiental, poluindo o ar e aumentando as doenças respiratórias no inverno. José Goldemberg, na época secretário do Meio Ambiente do Estado de São Paulo, formulou a Lei Estadual n. 11.241/02, que dispõe sobre a eliminação gradativa da queima da palha de cana ${ }^{21}$.

Além da lei, houve também o estabelecimento de uma parceria entre a Secretaria Estadual de Meio Ambiente, a Secretaria Estadual de Agricultura e Abastecimento e a Unica, permitindo o estabelecimento do Protocolo Agroambiental, que estimulou uma ação voluntária de intensificação rápida do corte mecanizado da cana pela indústria sucroenergética, o que possibilitou o atingimento dos $90 \%$ de colheita sem queima.

Hoje, a colheita de "cana crua" (sem queima, Figura 49) já é praticada em mais de 90\% da área colhida em São Paulo, onde é cultivada mais de 50\% da cana do Brasil. No entanto, a colheita de cana sem queimar introduziu um novo desafio tecnológico: como colher mecanicamente e economicamente a cana integral sem compactar o solo, danificar a soqueira e trazer muitas impurezas para a indústria. Na época, houve grande preocupação com o desemprego na zona rural, e o Projeto Renovação da Unica permitiu a requalificação dos cortadores de cana (4.350 trabalhadores requalificados apenas na safra 2012/2013, segundo a Unica).

21 Ver $<$ www.novacana.com/n/cana/colheita/safra-fim-queimadas-sp-180313/>. 


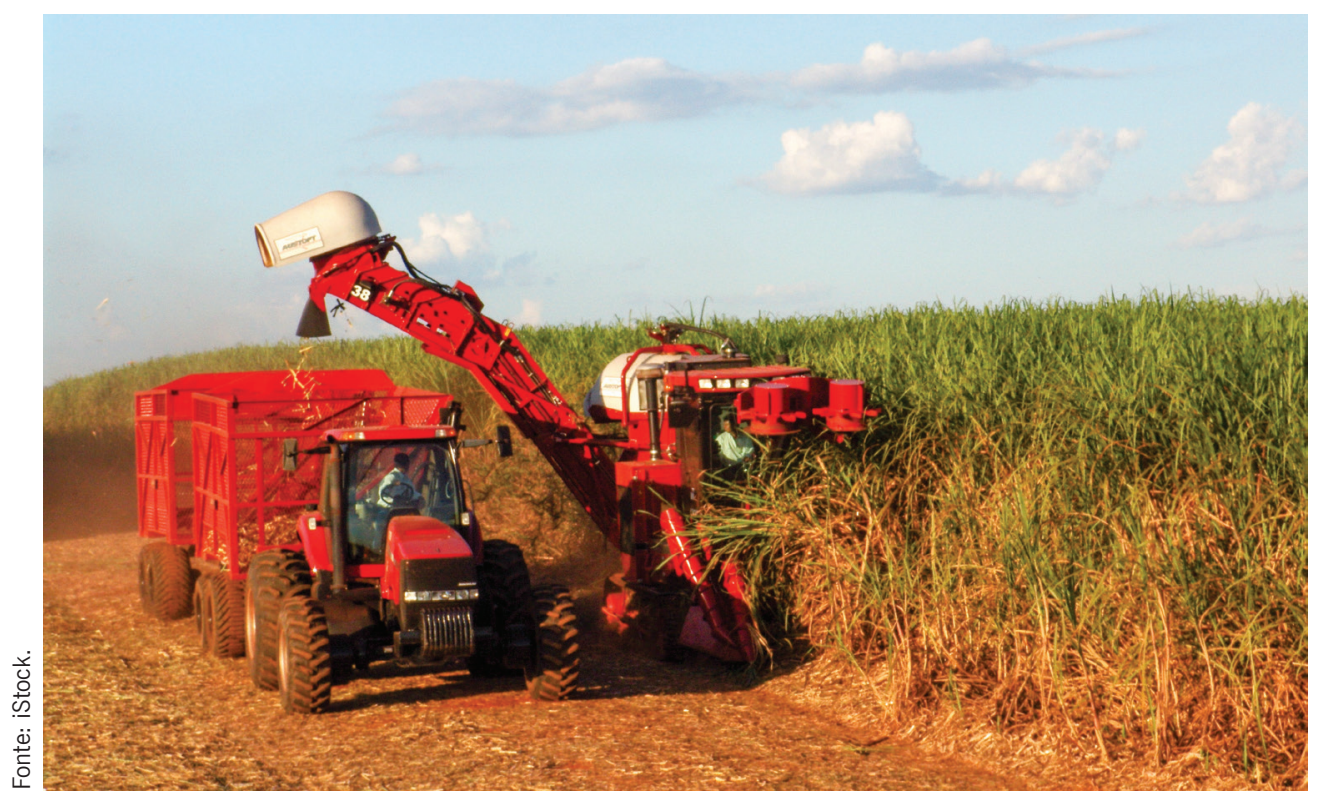

Figura 49: Colheita mecanizada de cana-de-açúcar, sem queima.

Oscar Braunbeck, então na Unicamp e hoje no Laboratório Nacional de Ciência e Tecnologia do Bioetanol (CTBE), preocupado com o impacto da mecanização sobre a mão de obra, desenvolveu o projeto Unimac $^{22}$ na Faculdade de Engenharia Agrícola (Feagri/Unicamp). Essa tecnologia de colheita "semimecanizada" possibilita o uso de mão de obra nas operações de corte e ordenamento da cana, as quais requerem mais habilidade que esforço físico (Figura 50). Esse tipo de método de colheita pode ser interessante para regiões mais declivosas e onde a questão social seja mais crítica. Fizeram parte desse desenvolvimento Paulo Graziano Magalhães e membros da spin-off Agricef.

Presentemente, Oscar Braunbeck desenvolve no CTBE uma Estrutura de Tráfego Controlado (ETC), que embute o desenvolvimento de processo de colheita multilinhas, integral de colmos e palha, focado na nova realidade, com redução de custos por meio da redução do tráfego, além de aumento da capacidade de colheita e da longevidade do canavial.

22 O projeto Unimac foi desenvolvido em cooperação com a spin-off Agricef, de ex-alunos de pós-graduação da Feagri/Unicamp. 


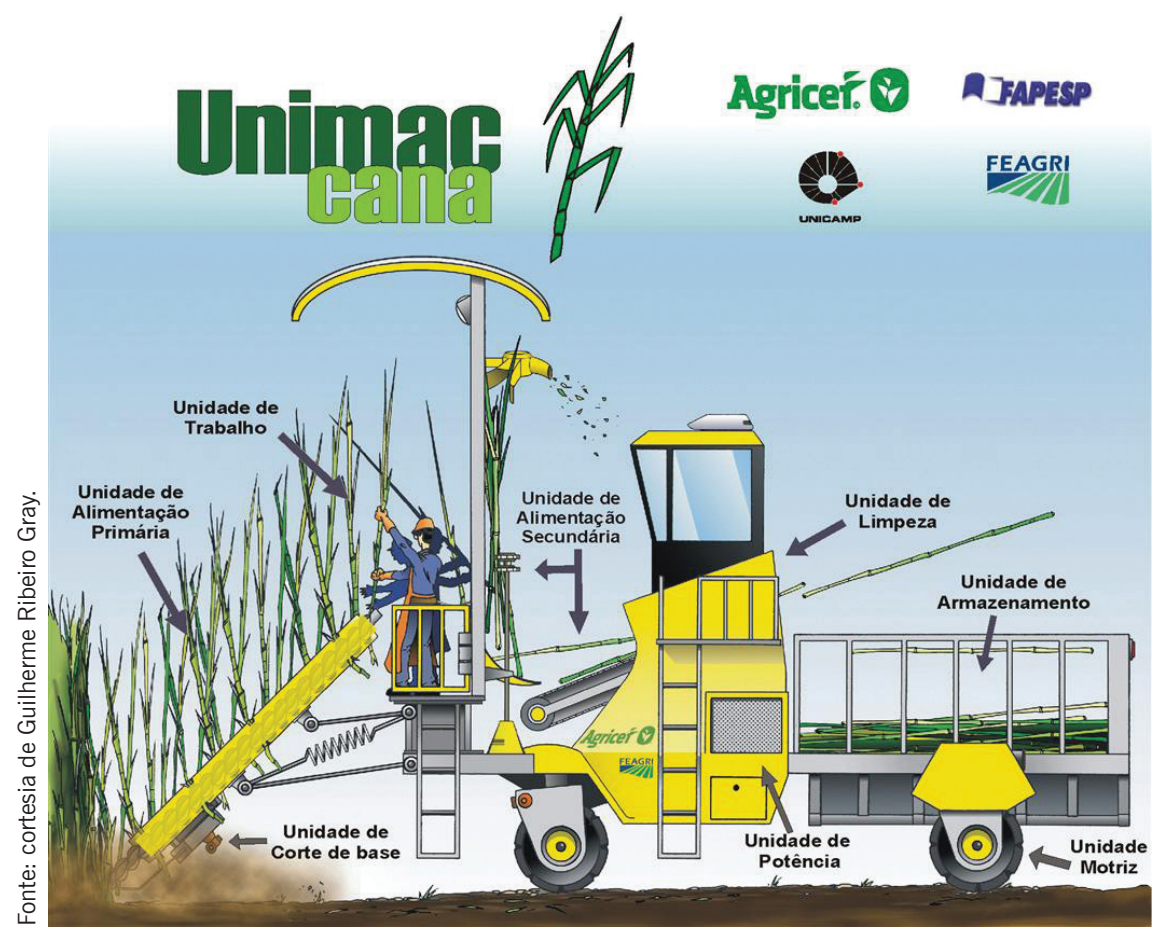

Figura 50: Projeto Unimac desenvolvido como sistema "semimecanizado" de colheita de cana-de-açúcar.

Com o fim das queimadas, aparece a palha de cana...

O fim das queimadas dos canaviais, que aconteceu principalmente no estado de São Paulo, trouxe à tona a questão da utilização da palha. Até então, quando a cana era queimada, a palha era eliminada com a queima, para facilitar a colheita que era feita manualmente, com poucas exceções. $O$ fim das queimadas praticamente representou o fim do corte manual ${ }^{23}$ e trouxe também uma importante pergunta: o que fazer com a palha? Um pesquisador que se destacou nessa fase, caracterizada pela quantificação e valorização da palha, tanto do ponto de vista energético como fertilizante, foi Tomaz Caetano Cannavan Rípoli, da ESALQ/USP. Com Rípoli ficou cunhado o termo “palhiço de cana” (Rípoli, 1991).

23 Apenas a "cana muda", ou seja, a cana que será utilizada como muda segue sendo colhida manualmente, e sem queimar. 
Vários trabalhos posteriormente realizados pelo CTC e pelo CTBE elucidaram questões econômicas e ambientais do "rateio" da palha, quanto deveria ficar no campo e quanto poderia ser levado à usina para posterior aproveitamento energético. Entre os pesquisadores do CTC que se destacam nos estudos sobre a palha encontram-se Jorge Luis Donzelli e Suleiman José Hassuani. Os estudos de Donzelli referem-se à quantidade de palha a ser deixada no campo e seus benefícios agronômicos. Já os trabalhos de Hassuani referem-se à limpeza da cana quando da chegada à usina para o processo, bem como às rotas de recolhimento de palha.

O fim da queimada e correspondente início da colheita mecanizada de cana crua significaram uma mudança no processo de limpeza da cana, anteriormente feito com o uso de água, por meio da lavagem da cana. Com a introdução da colheita mecanizada, a cana passou a ser colhida não inteira, como no corte manual, mas picada em toletes. Os toletes são muito mais suscetíveis à perda de açúcar no processo de limpeza com água. Assim, as usinas passaram a utilizar a limpeza de cana "a seco", com ar, reduzindo o consumo industrial de água, mas levando um pouco mais de impurezas ao processo. Esse tema, embora ainda não suficientemente estudado, tem merecido atenção dos pesquisadores no Brasil.

\section{2-2003: outro capítulo na guerra comercial do açúcar e etanol, dessa vez com os europeus}

O Brasil acusou a União Europeia de exportar açúcar com subsídios, no que foi acompanhado pela Austrália e Tailândia. Em 2002, a União Europeia era a segunda exportadora mundial da commodity, com 7,5 milhões de toneladas exportadas por ano. A ação é conduzida na Organização Mundial de Comércio (OMC, ou, em inglês, World Trade Organization - WTO), sob a coordenação da recém-criada Coordenadoria de Contenciosos do Ministério das Relações Exteriores (MRE), chefiada pelo então conselheiro Roberto Carvalho de Azevedo (posteriormente nomeado embaixador e atual diretor geral da OMC). O estudo que norteou o contencioso pelo Brasil, e acabou servindo de peça principal para a decisão do Órgão de Solução de Controvérsias da OMC, foi elaborado por Plínio Nastari, da Datagro, tornando-se conhecido como o "Undisputed Datagro Report". 


\section{3: criação do Canasat}

Com o Protocolo Etanol Verde, uma iniciativa do governo estadual paulista e do setor sucroenergético, antecipa-se o fim do prazo de colheita queimada no estado de São Paulo para 2014 nas áreas mecanizáveis (superiores a 150 ha e declividade máxima de 12\%) e fica prevista a concessão anual de um certificado de conformidade aos produtores que adotarem boas práticas de manejo. Nesse sentido, é estruturado o consórcio Canasat entre Fapesp, CTC, Unica, Divisão de Sensoriamento Remoto (DSR) e Divisão de Sensoriamento Remoto Aplicado à Agricultura e Floresta (LAF), estes dois últimos do Instituto Nacional de Pesquisas Espaciais (INPE), com vistas ao monitoramento por satélite da área e da colheita de cana-de-açúcar (Figura 51).

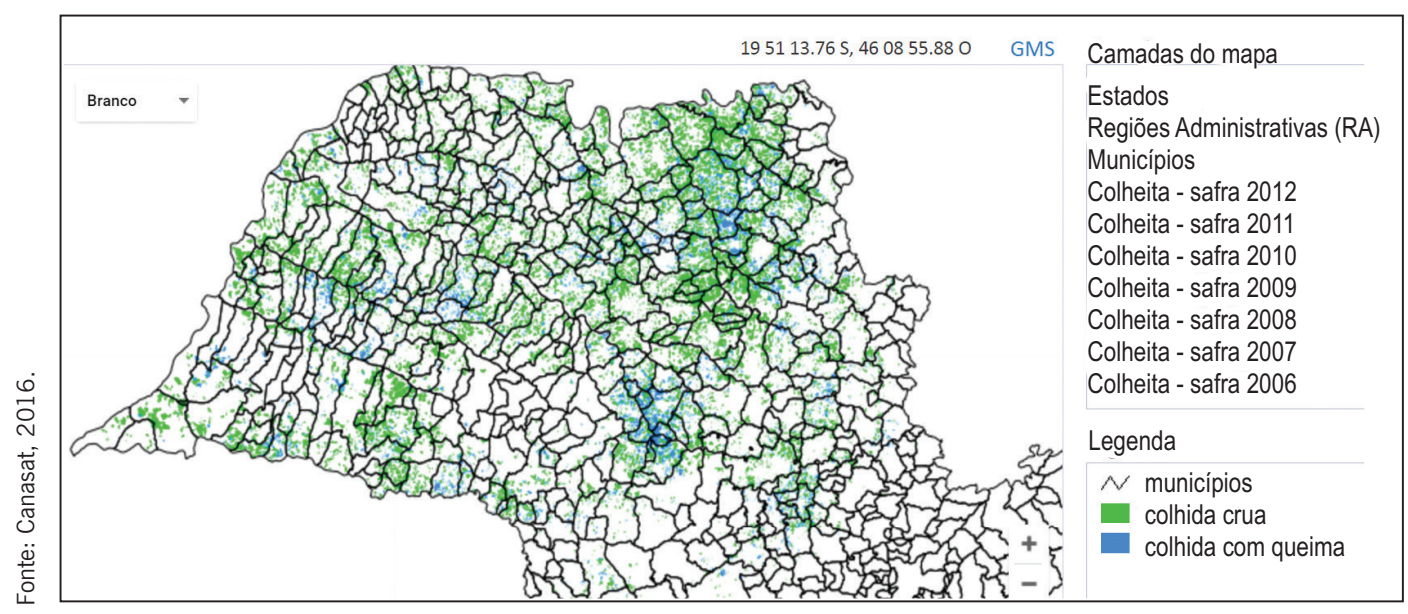

Figura 51: Monitoramento da colheita de cana-de-açúcar pelo Canasat.

\section{Curva de aprendizado}

O aumento da escala de produção em vários mercados tende a diminuir os custos unitários, inclusive pela incorporação de novas tecnologias. José Goldemberg constatou a redução dos custos à medida que um volume maior de etanol passou a ser produzido. Como o etanol é um substituto da gasolina, seu preço de venda está ligado ao custo da gasolina. Em um mercado de preços crescentes de gasolina, a 
diminuição dos custos do etanol resultou no cruzamento das curvas de custo dos dois combustíveis em torno do ano 2000.

Mas os preços do petróleo também podem diminuir, pressionando, assim, a competitividade do etanol. A curva correspondente a esse custo decrescente é a learning curve, ou curva de aprendizado (Figura 52), que mostra que no Brasil o etanol de cana-de-açúcar já não precisava mais de subsídios governamentais desde 2000, ano a partir do qual, ao contrário, o etanol de cana passou a "subsidiar" a gasolina por meio das misturas (Goldemberg, 2007).

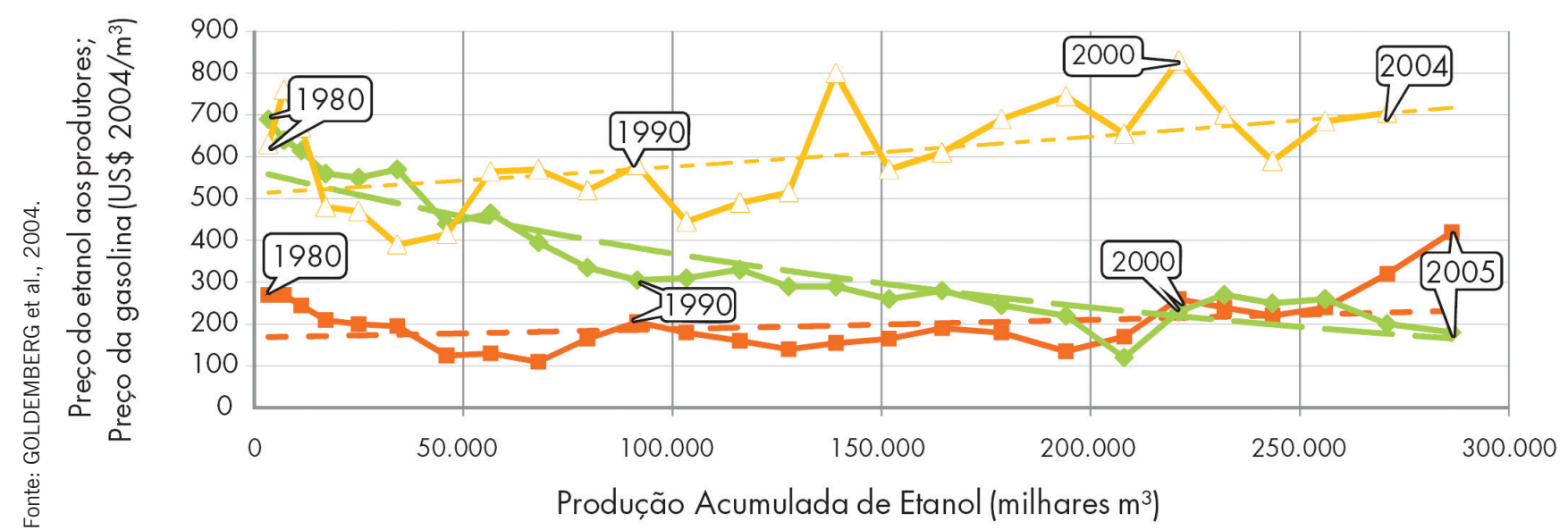

Figura 52: Curva de aprendizado do etanol de cana-de-açúcar no Brasil. Verde, preço do etanol BR; amarelo, preço da gasolina BR; laranja, preço da gasolina Rotterdam.

\section{Eficiência energética nas usinas}

A eficiência energética das usinas e destilarias tem melhorado no decorrer dos anos (Figura 53). Trabalhos pioneiros dessa análise foram os de Alan Poole e José R. Moreira (Poole; Moreira, 1979) e a tese de doutorado de Luiz A. Horta Nogueira, orientada por Isaías Macedo (Nogueira, 1987). Quanto à tecnologia industrial, incorporada nos equipamentos fornecidos pela indústria de bens de capital, trabalho pioneiro foi apresentado no I Painel Nacional de Excedentes de Bagaço (Olivério; Ordine, 
1987), com soluções integradas compondo uma usina de etanol que possibilitam excedentes de bagaço de até $78 \%$ do bagaço total contido na cana processada.

Outra referência importante na área de engenharia térmica foi o livro Uso de energia na indústria: racionalização e otimização, publicado pelo IPT em 1996, sobre o balanço energético e a cogeração nas usinas.

Posteriormente, destacam-se os esforços realizados pelo CTC no projeto Global Environment Facility (GEF), com financiamento do Banco Mundial, para o desenvolvimento de estudos sobre rotas de recuperação de palha de cana e seu aproveitamento em um processo de gaseificação avançada, sobretudo a partir da ameaça de racionamento de energia elétrica, conhecida como “apagão", ocorrida em 2002.
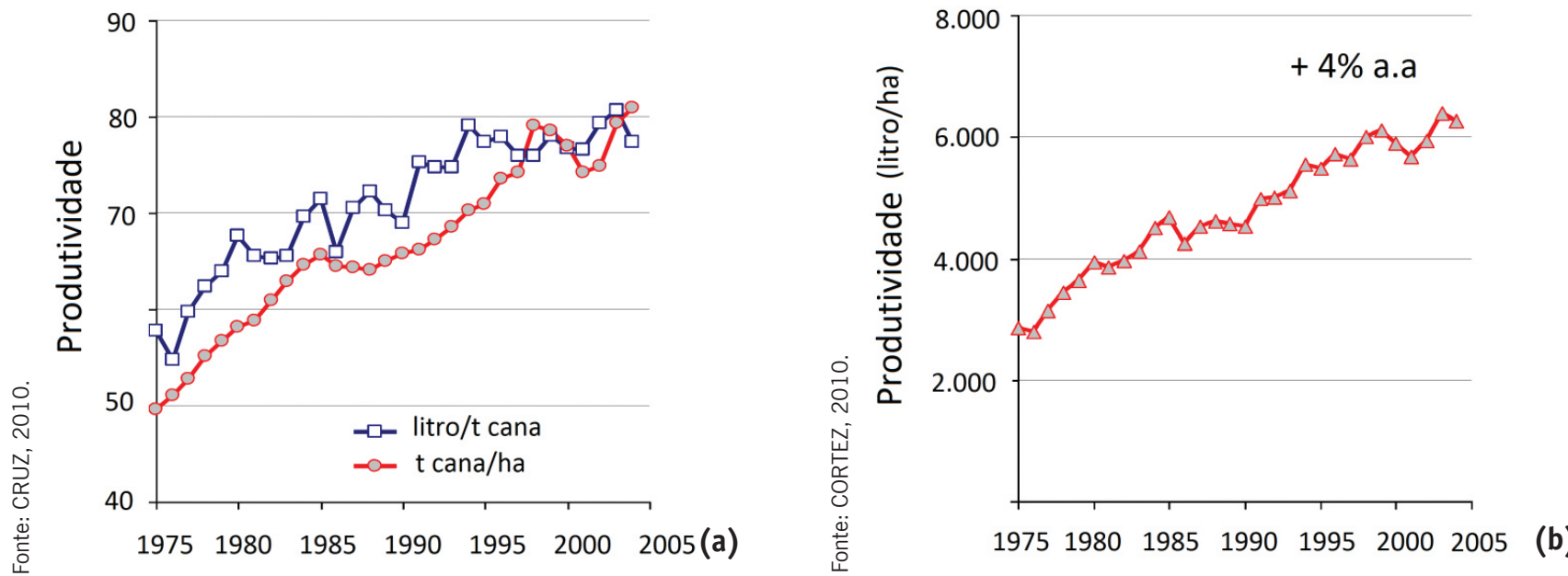

Figuras 53a e 53b: Evolução da produtividade agroindustrial do etanol de cana-de-açúcar no Brasil de 1975 a 2005.

Poucos setores conseguiram um incremento na sua eficiência total como o alcançado pelo setor sucroalcooleiro, de cerca de $4 \%$ ao ano. Isso foi possível graças ao efeito combinado do aumento de produtividade na agricultura da cana-de-açúcar e da eficiência industrial.

Os avanços na área de fermentação, por exemplo, foram significativos. Adotando uma estratégia de diminuição do tempo de fermentação visando à redução de custos, o tempo de fermentação caiu de quinze horas em 1975 para oito horas já em 1990 (Figura 54). 
Entre os grupos de pesquisa que contribuíram para avanços na área de fermentação estão o da Faculdade de Engenharia de Alimentos da Unicamp, com Francisco Maugeri Filho, e seu processo de fermentação extrativa $^{24}$ e também o de Sílvio Roberto Andrietta, um dos expoentes em fermentação alcoólica no Brasil.

Uma novidade desenvolvida no país, no campo da destilação, já é responsável por quase um terço da produção de etanol (Oliveira e Vasconcelos, 2006). Trata-se de um processo de desidratação do etanol, conhecido como destilação extrativa, um método para a produção do álcool anidro que é adicionado à gasolina. Depois da etapa de destilação, que separa uma mistura líquida de componentes, o etanol hidratado ainda tem cerca de $4 \%$ de água.

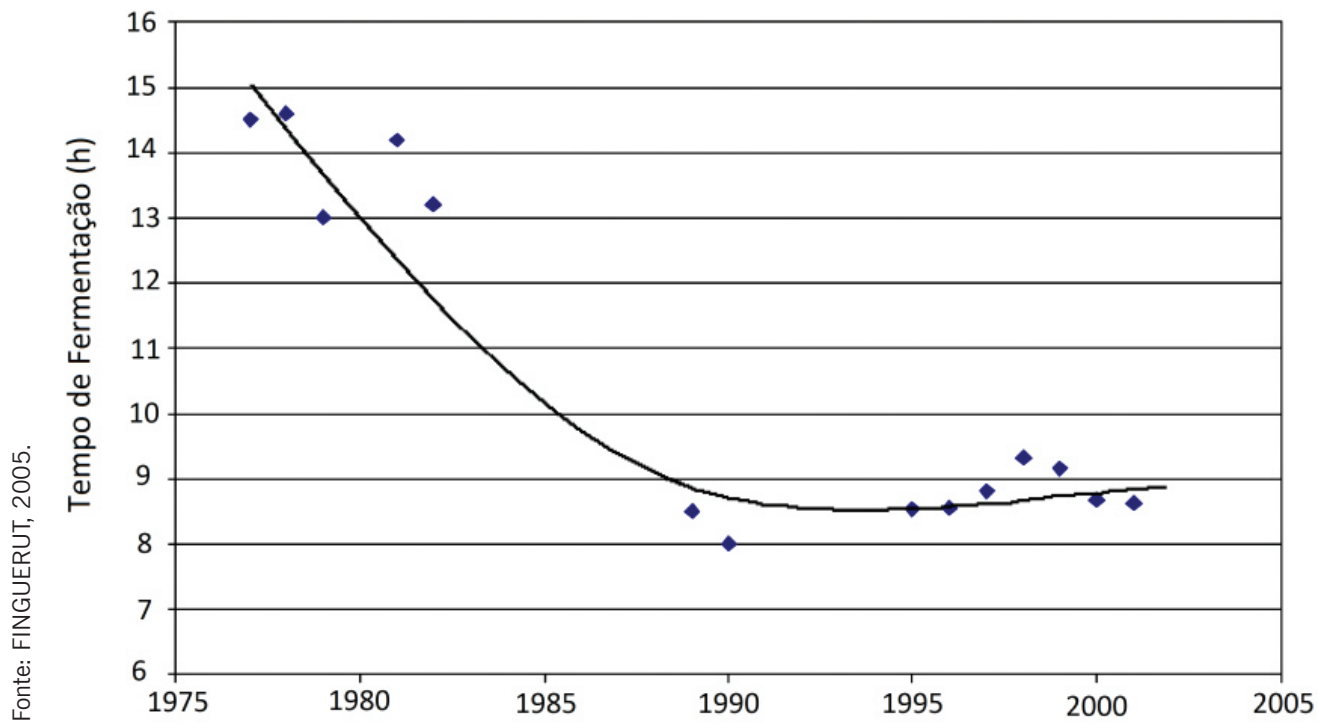

Figura 54: Evolução do tempo de fermentação do etanol de cana-de-açúcar no Brasil de 1975 a 2005.

"Pela técnica de destilação extrativa, um terceiro componente, o monoetileno glicol (MEG) é adicionado, o qual reduz a volatilidade da água, permitindo a vaporização do etanol. Em seguida, o álcool é condensado, gerando o etanol anidro. O monoetileno glicol, por sua vez, é purificado e retorna para 
a primeira fase do processo", diz Antonio José de Almeida Meirelles, da Faculdade de Engenharia de Alimentos da Unicamp, que estudou o processo e participou da transferência da tecnologia para o setor industrial. "A destilação com MEG, ante o método convencional, reduz pela metade o consumo de vapor para destilar o etanol anidro." Introduzida no setor produtivo em 2001, a nova destilação já foi adotada por 28 usinas e responde pela produção de mais de 2,5 bilhões de litros de álcool anidro por ano, cerca de $30 \%$ do total produzido no país. Hoje, no entanto, há também outras tecnologias bastante utilizadas, como a do ciclohexano, peneira molecular e membranas.

As melhorias envolvendo a moagem, fermentação, destilação e combustão nas caldeiras podem ser vistas na Tabela 2.

Tabela 2: Melhorias tecnológicas nas usinas

\begin{tabular}{lcc}
\hline & 1975 & 2005 \\
\hline Capacidade de moagem-moenda 6 × 78" (t cana/dia) & 5.500 & 14.000 \\
\hline Tempo de fermentação (h) & 16 & 8 \\
\hline Eficiência de extração (\%) & 93 & 97 \\
\hline Eficiência de fermentação (\%) & 82 & 91 \\
\hline Eficiência de destilação (\%) & 98 & 99,5 \\
\hline Eficiência global da destilaria (\%) & 66 & 86 \\
\hline Eficiência das caldeiras (\%) & 66 & 88 \\
\hline
\end{tabular}

Fonte: Leal (2008) apud J. Olivério e J. Finguerut.

De acordo com informações fornecidas por Henrique de Amorim, da empresa Fermentec, muito do avanço tecnológico obtido na moagem da cana deveu-se à Copersucar. Na época, o CTC contratou os melhores técnicos da África do Sul para melhorar o sistema de moagem, fazendo a eficiência de extração subir de 89\% para 95\% no período. Em seguida, desenvolveram-se moendas de menor custo e com maior capacidade de extração do que as encontradas na África do Sul.

Ainda segundo Amorim, a fermentação "era residual", as melhores usinas tinham eficiência de $75 \%$. Nesse sentido, grandes foram as contribuições para o aumento da eficiência da fermentação por José Paulo Stupiello, da ESALQ/USP, e o próprio Henrique Vianna de Amorim, da Fermentec. 
Uma área transversal nos processos industriais refere-se ao desenvolvimento de sensores. O grupo de pesquisas de Nelson Ramos Stradiotto, do Instituto de Química da Unesp em Araraquara, tem desenvolvido pesquisas nas áreas de química analítica e físico-química nas especialidades de eletroquímica e eletroanalítica. Essa temática de pesquisa está relacionada com sensores e detectores eletroquímicos e métodos eletroanalíticos na área de biocombustíveis.

\section{5: Seminário da Unicamp em comemoração aos 30 anos do Proálcool}

Em novembro de 2005, a Unicamp realizou em Campinas um simpósio comemorativo dos trinta anos do Proálcool, intitulado: 1975-2005 - Etanol combustível: balanço e perspectivas - evento comemorativo dos 30 anos da criação do Proálcool. O evento se deu em um momento de grande expansão do setor sucroenergético, impulsionado principalmente pelo crescimento acelerado da demanda de etanol decorrente do sucesso comercial dos veículos flex-fuel, que representavam cerca de $80 \%$ dos veículos leves produzidos no Brasil.

Inúmeros foram os temas discutidos, entre eles, o da tecnologia da indústria de equipamentos e os avanços obtidos muitas vezes decorrentes de parcerias entre o setor privado e os centros públicos de pesquisa.

O setor sucroenergético é um dos maiores exemplos de como a indústria nacional de equipamentos está apta a responder com rapidez e eficiência às necessidades do mercado, oferecendo produtos de qualidade e tecnologicamente atualizados no estado da técnica, com mínima importação e índice de nacionalização próximo de $100 \%$.

O fator de indução desse desenvolvimento foi o mercado, e pode-se concluir que a razão dessa evolução tecnológica foi a existência e permanência de demanda originada pelo crescimento acelerado que se verificou na expansão do setor sucroenergético brasileiro. A Figura 55 esquematiza como se deu esse desenvolvimento em nosso país. 
ÁLCOOL - A EVOLUÇÃO TECNOLÓGICA E A INDÚSTRIA DE EQUIPAMENTOS

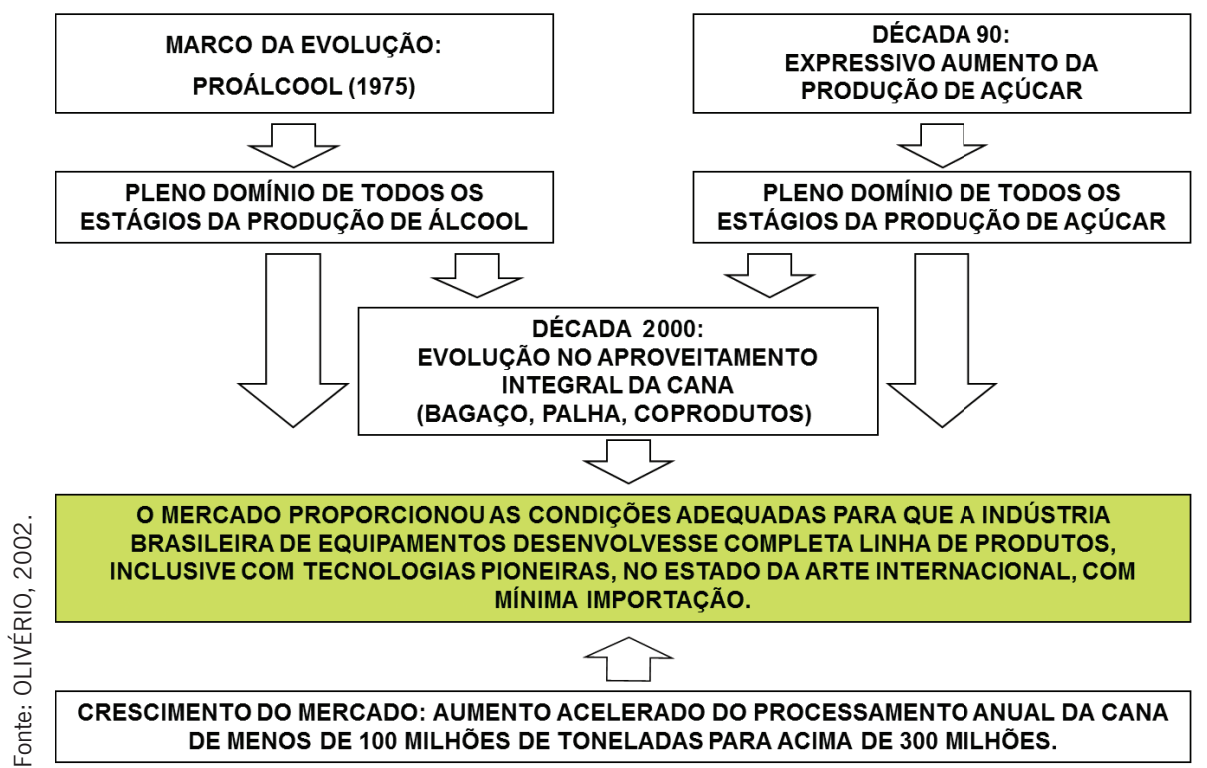

Figura 55: A evolução tecnológica e a indústria de equipamentos.

A evolução da tecnologia se deu nas três naturezas de fornecimentos típicos dessa indústria: em equipamentos, em processos e em unidades (plantas) ou usinas completas, com total abrangência nos diferentes estágios de conhecimento, iniciando com o domínio da pesquisa e desenvolvimento e passando pela engenharia processual, básica e detalhada, e pela implantação e a operação eficiente das unidades. Os fabricantes de equipamentos em seu conjunto possuem tecnologia própria e completa, desenvolvimento próprio e foram pioneiros na introdução mundial de inúmeras inovações tecnológicas. A Figura 56 ilustra como se processa essa evolução, que seguiu cinco grandes estágios:

- Aumento da capacidade dos equipamentos.

- Aumento dos rendimentos. 
- Maior aproveitamento da energia da cana-de-açúcar.

- Maior aproveitamento de produtos e subprodutos da cana-de-açúcar.

- A usina de açúcar e álcool definida como uma unidade produtora de energia e alimentos.

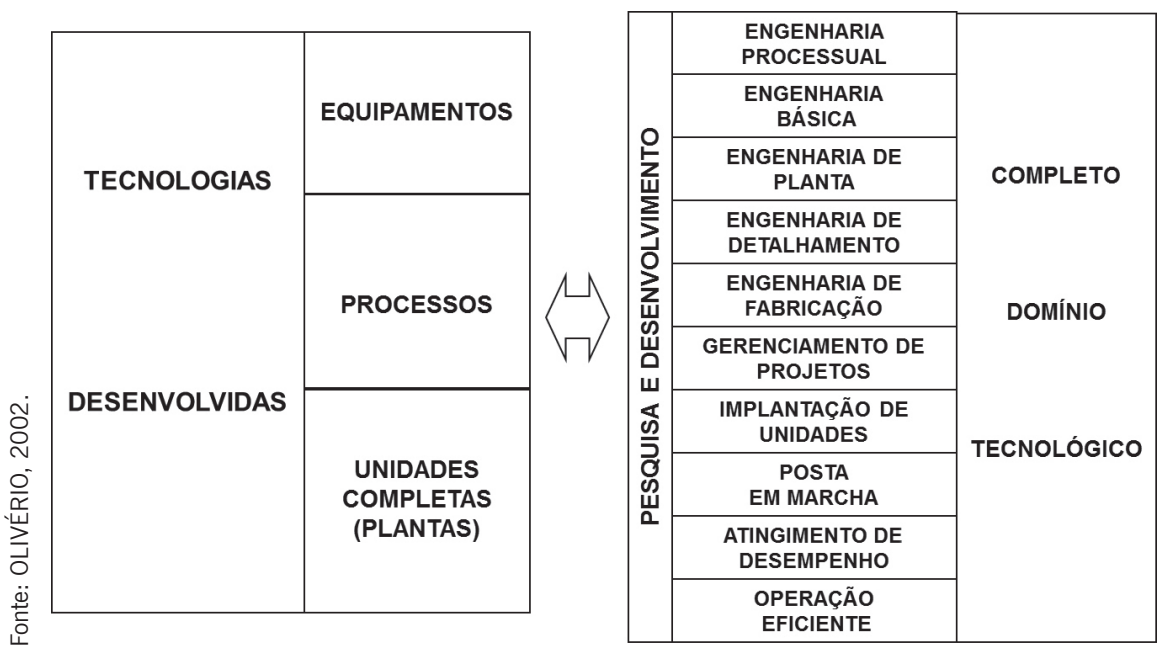

Figura 56: As diversas tecnologias da indústria de equipamentos.

Esse desenvolvimento industrial se deu pela interação e integração dos quatro pilares que promoveram e sustentaram essa evolução tecnológica (Olivério, 2005):

- Usinas de açúcar e as destilarias de etanol.

- Institutos e centros de tecnologia, aí incluídas as universidades.

- Conjunto de consultores especializados.

- Fabricantes de equipamentos. 
Como resultado dessa acentuada evolução tecnológica, ocorreu sensível crescimento das produtividades, rendimentos e eficiências do setor industrial do agronegócio da cana-de-açúcar nos primeiros trinta anos do Proálcool, (Olivério, 2005b), conforme Tabela 3.

Tabela 3: Resultados da evolução tecnológica do setor industrial (1975 a 2005)

\begin{tabular}{|c|c|c|c|}
\hline Parâmetros & Produtos Dedini & $\begin{array}{l}\text { Início do } \\
\text { Proálcool }\end{array}$ & 2005 \\
\hline Capacidade de moagem (TCD) $-6 \times 78^{\prime \prime}$ & DH1/MCD01 & 5.500 & 13.000 \\
\hline Tempo de fermentação (h) & CODISTIL Ferm. Bat/Cont & 24 & 6 \\
\hline Teor alcoólico do vinho ( $\left.{ }^{\circ} \mathrm{GL}\right)$ & CODISTIL Fermentação & 7,5 & 10,0 \\
\hline Rendimento extração ( $\%$ aç. cana) -6 ternos & DH1/MCD01/Difusor & 93 & 97 \\
\hline Rendimento fermentativo (\%) & CODISTIL Ferm. Bat/Cont & 80 & 91 \\
\hline Rendimento da destilação (\%) & Destiltech & 98 & 99,5 \\
\hline Rendimento total (L álc.hidr./t cana) & Tecnologia CODISTIL & 66 & 86 \\
\hline Consumo total de vapor (kg/t cana) & Tecnologia CODISTIL & 600 & 380 \\
\hline Consumo de vapor-hidratado (kg/L) & Destiltech & 3,4 & 2,0 \\
\hline Consumo vapor-anidro (kg/L) & Destiltech (+) Destilplus/Peneira Molecular & 4,5 & 2,8 \\
\hline Caldeira-Eficiência (\% PCI) & AZ/AT/COGEMAX & 66 & 87 \\
\hline Pressão (bar)/Temperatura $\left({ }^{\circ} \mathrm{C}\right)$ & AZ/AT/COGEMAX & $21 / 300$ & $85 / 530$ \\
\hline Bagaço excedente (\%) - usina de álcool & Tecnologia CODISTIL & até 8 & até 78 \\
\hline Biometano a partir de vinhaça ( $\mathrm{Nm}^{3} / \mathrm{L}$ álc) & METHAX & - & 0,1 \\
\hline Produção de vinhaça (L vinhaça/l álcool) & BIOSTIL & 13 & 0,8 \\
\hline
\end{tabular}

Siglas: TCD, Toneladas de Cana por Dia; PCI, Poder Calorífico Inferior, baseado no bagaço. 


\section{Sustentabilidade na produção do etanol}

Sustentabilidade do etanol de cana é um conceito que se apoia em três pilares: econômico, social e ambiental. Sendo a sustentabilidade econômica um componente fundamental, é por vezes colocada como uma condição sine qua non para o sucesso de uma alternativa energética. Nesse sentido, a curva de aprendizagem proposta por Goldemberg mostrou como os custos de produção diminuíram ao longo dos anos.

Várias instituições de pesquisa deram contribuições significativas na área de sustentabilidade, como é o caso do IPT com as pesquisas sobre biodigestão de vinhaça, e de Américo Martins Craveiro (Craveiro et al., 1986) e do INT visando reduzir seu impacto poluente. Atualmente, Marcelo Zaiat, do Centro de Pesquisa, Desenvolvimento e Inovação em Engenharia Ambiental da Escola de Engenharia de São Carlos/USP, é um dos mais destacados pesquisadores na área de biodigestão de vinhaça, sendo seus estudos voltados principalmente à integração do aproveitamento desse resíduo nas fases agrícola e industrial do processo de produção de etanol.

Na sustentabilidade social da cana-de-açúcar, o Brasil fez importantes avanços a partir de meados do ano 2000. As condições de trabalho (formalização de emprego, idade dos trabalhadores, cumprimento das normas trabalhistas), além de melhorarem significativamente, apresentam indicadores melhores do que a maioria das atividades agropecuárias (segundo comunicação de Márcia Azanha Ferraz Dias de Moraes). Exemplificando, os empregos com carteira assinada na cultura da cana no Brasil atingem ao redor de $80 \%$, enquanto a média agropecuária gira em torno de $40 \%$. No estado de São Paulo, esse percentual é de aproximadamente $90 \%$.

Isaías Macedo (Figura 57) e Manoel Regis Lima Verde Leal, na época ambos do CTC, deram importante contribuição para a sustentabilidade energética e ambiental do etanol. O livro A energia da cana-de-açúcar: doze estudos sobre a agroindústria da cana-de-açúcar no Brasil e a sua sustentabilidade, publicado pela Unica em 2005 e coordenado por Macedo, aborda os principais aspectos nessa área.

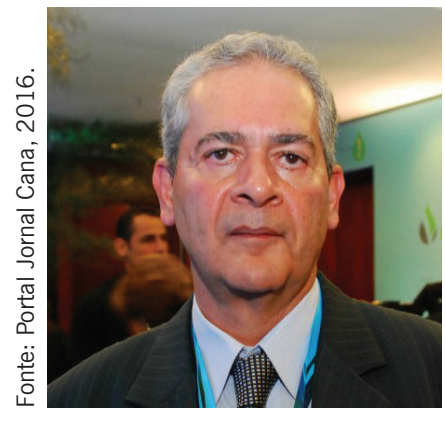

Figura 57: Isaías Macedo. 


\section{A construção do modelo brasileiro de produção simultânea de açúcar e etanol}

Várias contribuições foram importantes na produção industrial, tanto para açúcar e etanol para a criação do que é conhecido como o “modelo brasileiro" de produção simultânea. José Paulo Stupiello (Figura 58) da ESALQ/USP e presidente da Sociedade Brasileira de Tecnólogos de Açúcar (STAB), é uma das referências em tecnologia de produção de açúcar no Brasil.

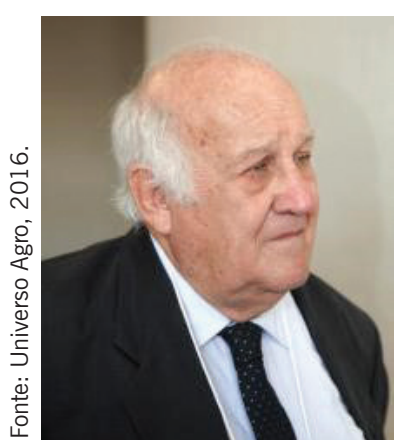

Figura 58: José Paulo Stupiello.

Fumio Yokoya, da Unicamp, é outra referência importante em microbiologia do etanol, tendo desenvolvido estudos fundamentais sobre a fermentação utilizando a cana e outras matérias-primas.

Já no CTC, Jaime Finguerut e Carlos Rossell foram dos muitos que contribuíram para "otimizar" o conceito das "usinas flex". Esses esforços resultaram em importantes contribuições à indústria do etanol, evidenciadas pela redução do tempo de fermentação.

Esse "modelo brasileiro" contém vários mecanismos que visam regular a oferta e demanda de etanol combustível em diferentes níveis. Os mecanismos podem ser divididos em três, como se segue:

Flexibilidade I: a cana-de-açúcar tem o seu melhoramento genético otimizado, visando maximizar o rendimento de sacarose por hectare. Dessa forma, a usina pode produzir mais açúcar quando o preço está mais elevado, e isso ajuda a equação econômica para produzir etanol mais barato. Normalmente, a maioria das usinas brasileiras pode ajustar seu processo para processar de $40 \%$ a $60 \%$ da sua sacarose em açúcar ou etanol, dependendo da situação econômica.

Flexibilidade II: no Brasil são produzidos dois tipos de etanol combustível: o hidratado e o anidro. O etanol hidratado (92\% em massa) é para ser usado diretamente em veículos E100 e em veículos flex-fuel. O etanol anidro é que deve ser misturado à gasolina para formar o combustível E18-27, também conhecido como "gasolina C". 
Portanto, quando há excesso de produção de etanol, além da consequente redução do preço na bomba, o governo pode aumentar a proporção misturada à gasolina. Como mais da metade do etanol produzido é do tipo hidratado, um excedente sazonal pode ser, assim, facilmente absorvido. Além disso, tipicamente, um ou dois meses antes da colheita de cana começar, há escassez de etanol hidratado, e o governo pode diminuir o percentual de anidro misturado na gasolina.

Uma vez que não há suficiente armazenamento de etanol no país, esse mecanismo de algum modo regula o mercado. Naturalmente, isso terá um efeito a montante nas usinas em que ambos os tipos de etanol são produzidos, o que requer equipamento adicional.

Flexibilidade III: não há veículos usando "gasolina pura” no Brasil desde meados dos anos 1970. A partir de 1979, os veículos E100, também conhecidos como carros a álcool, foram introduzidos, exigindo duas bombas diferentes em cada posto de gasolina no Brasil.

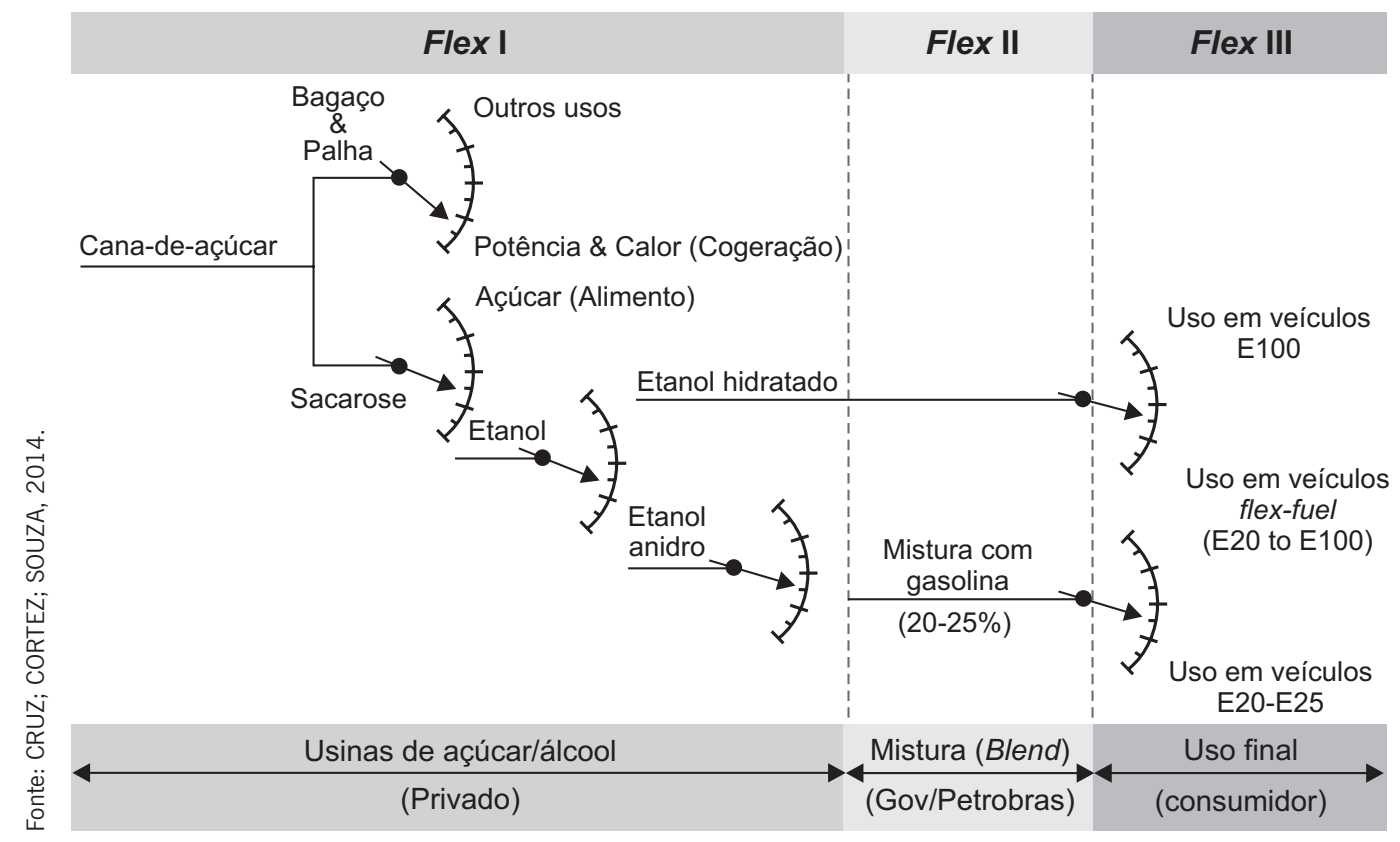

Figura 59: Os mecanismos de flexibilidade que constituem o "modelo brasileiro" para produção, conversão e uso do etanol combustivel no país. 
Isso foi feito, e de lá até 2014, tanto gasolina C (E18-E27) quanto E100 eram distribuídos em aproximadamente 39 mil postos de combustível em todo o país (Sindicom, 2014). No entanto, desde março de 2003, o veículo flex-fuel foi introduzido pelos fabricantes de automóveis para dar ao consumidor brasileiro uma outra opção: usar qualquer proporção de etanol (E100) e gasolina C (E18-E27).

Como regra usada pelos consumidores, quando o preço do etanol hidratado é inferior a $70 \%$ do preço da gasolina C, vale a pena usar o etanol hidratado (E100). Este terceiro nível de flexibilidade, orientado para satisfazer o consumidor, é considerado um sucesso de comercialização para o uso geral de etanol no país.

\section{A contribuição do uso do etanol combustivel sobre a saúde da população nas grandes cidades brasileiras}

Também em questões de saúde relacionadas com as emissões veiculares a comunidade acadêmica deu importante contribuição, com trabalhos pioneiros de György Miklós Böhm, da Faculdade de Medicina da USP. Paulo Saldiva (Figura 60), do Laboratório de Poluição Atmosférica da Faculdade de Medicina (USP), estudou como o uso de etanol combustível e a redução das emissões geradas na cidade de São Paulo, por mais de 5 milhões de carros (a maioria dos quais flex-fuel), ajudam a aliviar a contaminação do ar. Segundo Saldiva, o uso do etanol combustível, em substituição à gasolina, é uma importante medida de política pública na saúde da população brasileira que vive nas grandes cidades (Sousa e Macedo, 2011).

Destacam-se os estudos desenvolvidos pela Companhia de Tecnologia de Saneamento Ambiental (CETESB, atualmente Companhia Ambiental do Estado de São Paulo) sobre a emissão de poluentes atmosféricos pelos veículos a álcool e a gasolina, demonstrando que as emissões associadas ao uso do etanol (puro e em mistura com gasolina) apresentam menor impacto ambiental que as emissões associadas à gasolina pura. Merecem destaque os estudos desenvolvidos por Alfred Szwarc (Figura 61) e Gabriel Murgel Branco, na CETESB, no sentido de promover o uso em grande escala do etanol como estratégia para reduzir a poluição do ar.

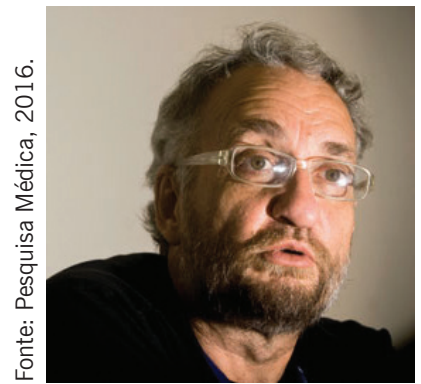

Figura 60: Paulo Saldiva.

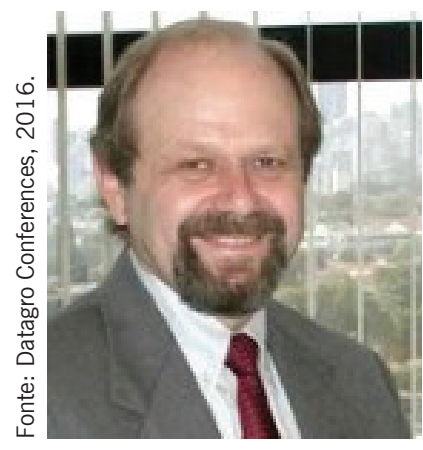

Figura 61: Alfred Szwarc. 


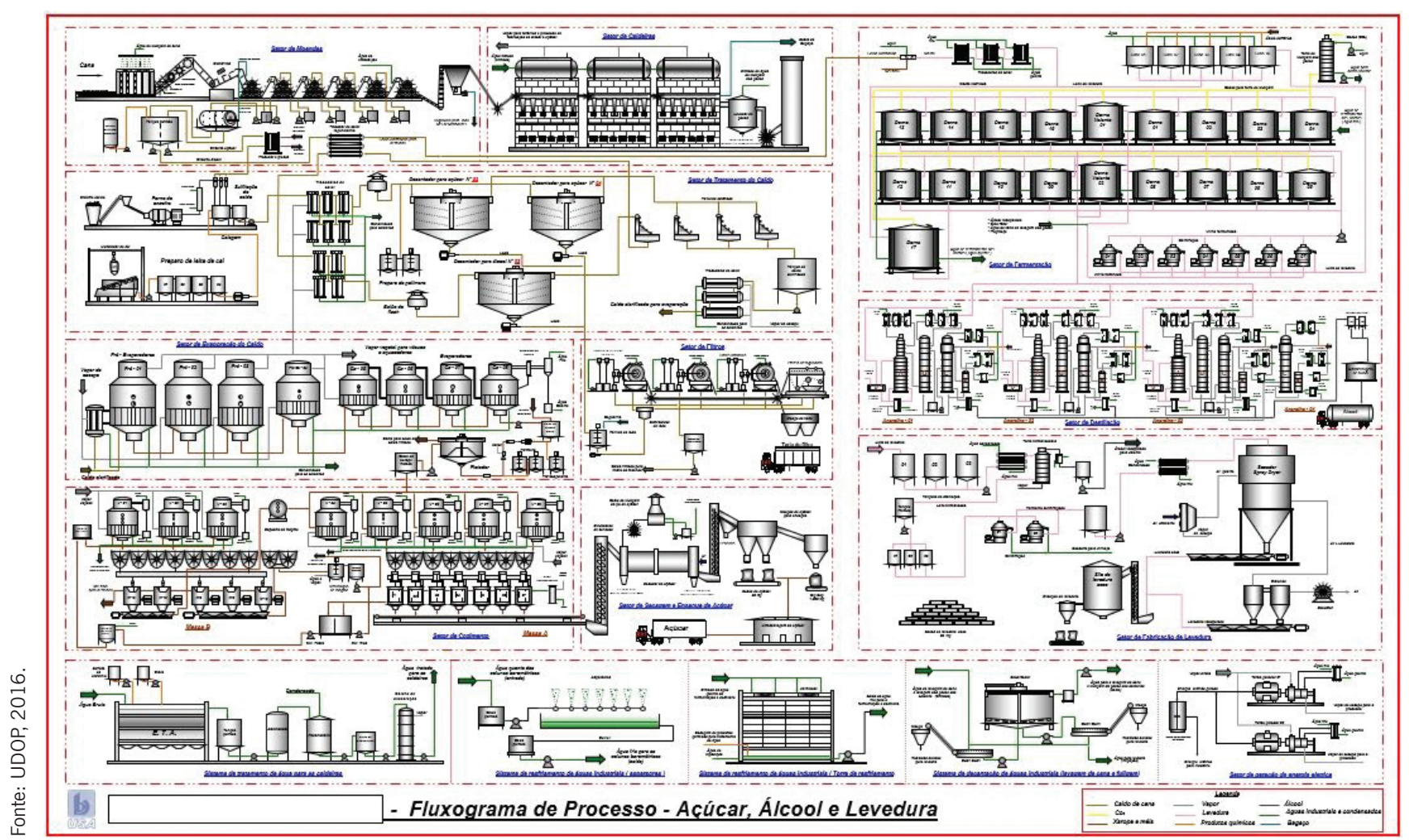

Figura 62: Fluxograma de uma usina de açúcar e álcool no Brasil.

Planejando o uso da terra para a bioenergia no Brasil

As perspectivas de rápida expansão da cana-de-açúcar para a produção de bioenergia voltada à exportação teve um importante impacto sobre o planejamento do uso da terra no Brasil. Valem menção os trabalhos conduzidos por André Nassar com o Brazilian Land Use Model (BLUM) e o Zoneamento Agroecológico da Cana-de-Açúcar, elaborado pelo Ministério da Agricultura, Pecuária e Abastecimento (MAPA) (Figura 63). Marcelo Moreira e outros pesquisadores do AgroÍcone também colaboraram para o BLUM. 


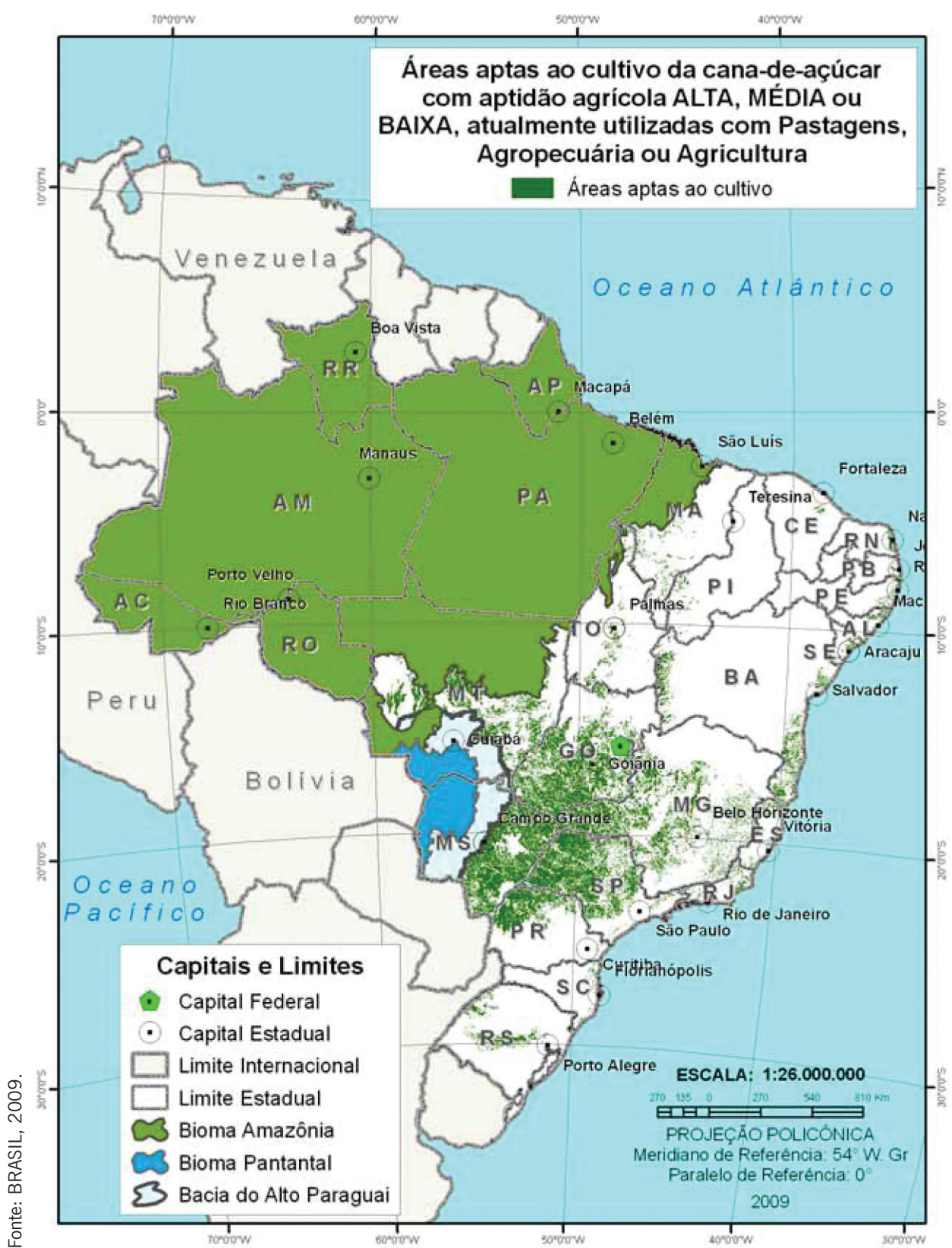

Figura 63: Zoneamento agroecológico da cana-de-açúcar no Brasil. 
O Zoneamento agroecológico da cana-de-açúcar no Estado de São Paulo foi realizado pelo programa Biota da Fapesp, coordenado por Carlos Joly do Instituto de Biologia da Unicamp (Figura 64).

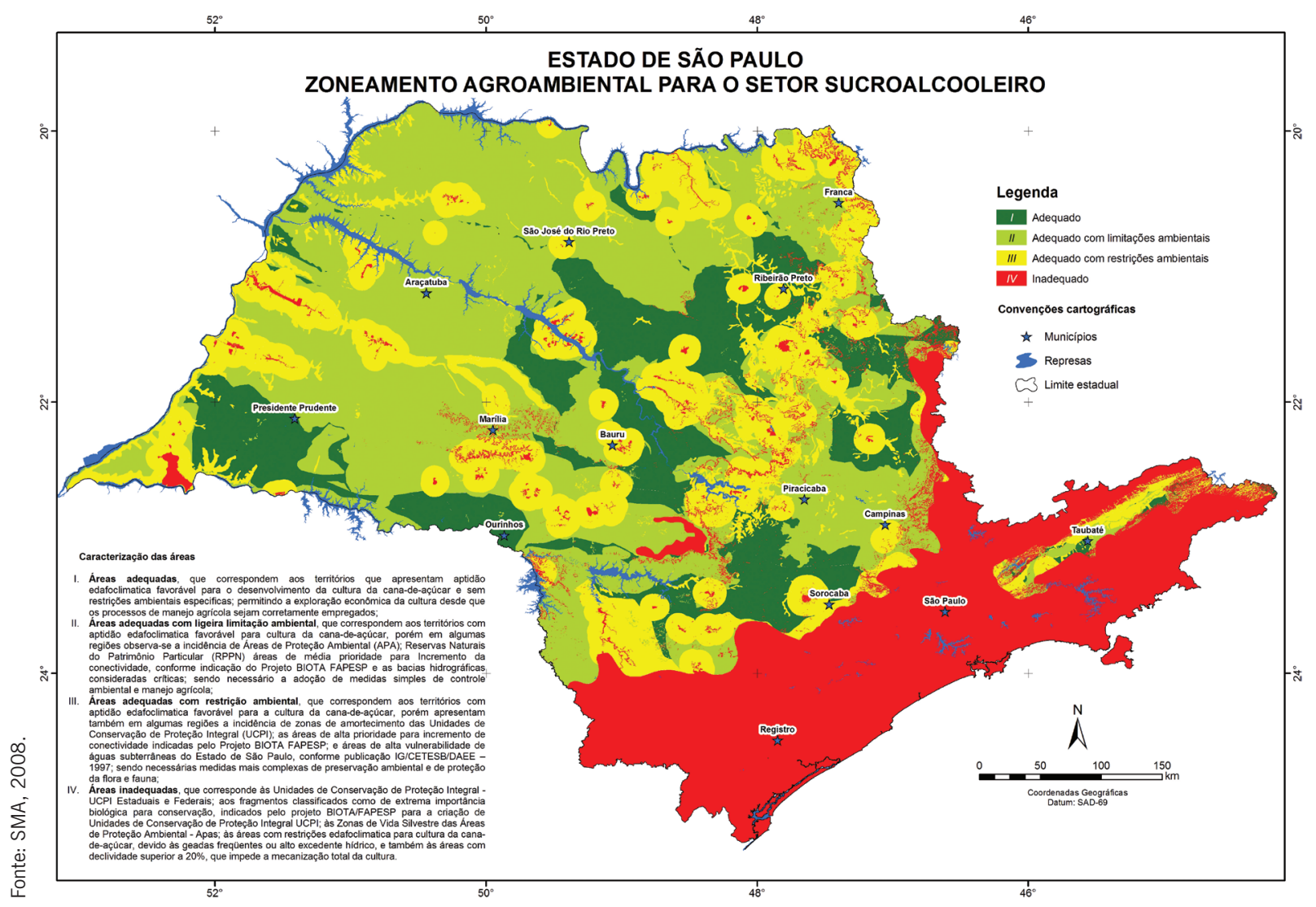

Figura 64: Zoneamento agroecológico da cana-de-açúcar no estado de São Paulo.

Observe-se que a área presentemente ocupada pela cana-de-açúcar no Brasil, de cerca de 9 milhões de hectares, equivale a $\mathbf{1 \%}$ do território nacional. Essa cana é utilizada basicamente para os fins de produzir açúcar, etanol e outros de menor expressão, como alimento animal, cachaça e rapadura. Segundo o IBGE, em 2008 , cerca de $0,6 \%$ da área total do país era destinada à produção de etanol combustível. 
Apesar dos avanços nas questões de sustentabilidade ligadas à área econômica, social e ambiental da produção e uso do etanol de cana-de-açúcar no Brasil, e dos esforços na sua comunicação, ainda há muita desinformação, principalmente em países que vivem realidades muito diferentes das existentes aqui.

Porém, algumas grandes transformações têm sido reconhecidas, como o fim das queimadas de cana no centro-sul brasileiro, redução do consumo de água nos processos industriais, regulação das dosagens de aplicação da vinhaça e proteção das matas ciliares vizinhas aos canaviais. Apesar disso, muito ainda está sendo feito para melhorar os indicadores relativos à sustentabilidade da produção (Filoso et al., 2015).

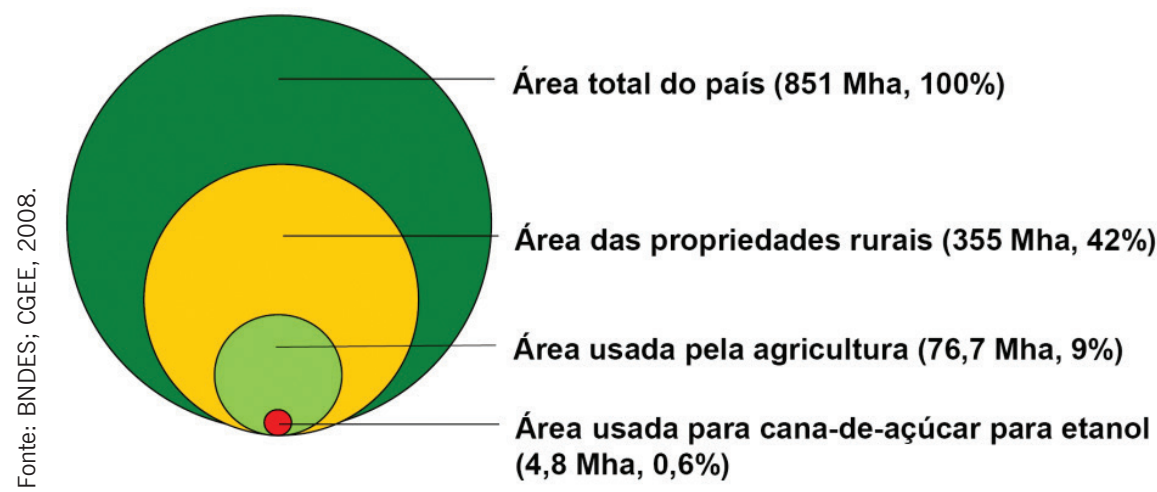

Figura 65: Na produção de etanol de cana-de-açúcar no Brasil utiliza apenas 0,6\% da área total do país.

\section{Avanços na aplicação de vinhaça}

O tema da vinhaça mereceu grande atenção, dado que os volumes produzidos desse efluente eram consideráveis, assim como seu potencial poluidor. Tradicionalmente, o processo de fermentação utilizado produz de 10 a 14 litros de vinhaça/litro de etanol.

O método de fermentação utilizado no Brasil é conhecido por Melle-Boinot (Figura 66), descrito em Valsechi (1944). Nesse processo se obtém, como foi dito anteriormente, quantidades expressivas de vinhaça. 
São duas as rotas tecnológicas de redução desse volume de vinhaça, sendo a primeira pelo uso de processos de fermentação com maior teor alcoólico, e a segunda por meio da evaporação, retirando-se parte da água da vinhaça e concentrando os resíduos sólidos no efluente remanescente. Já há processos industriais disponíveis no mercado que seguem esta segunda rota.

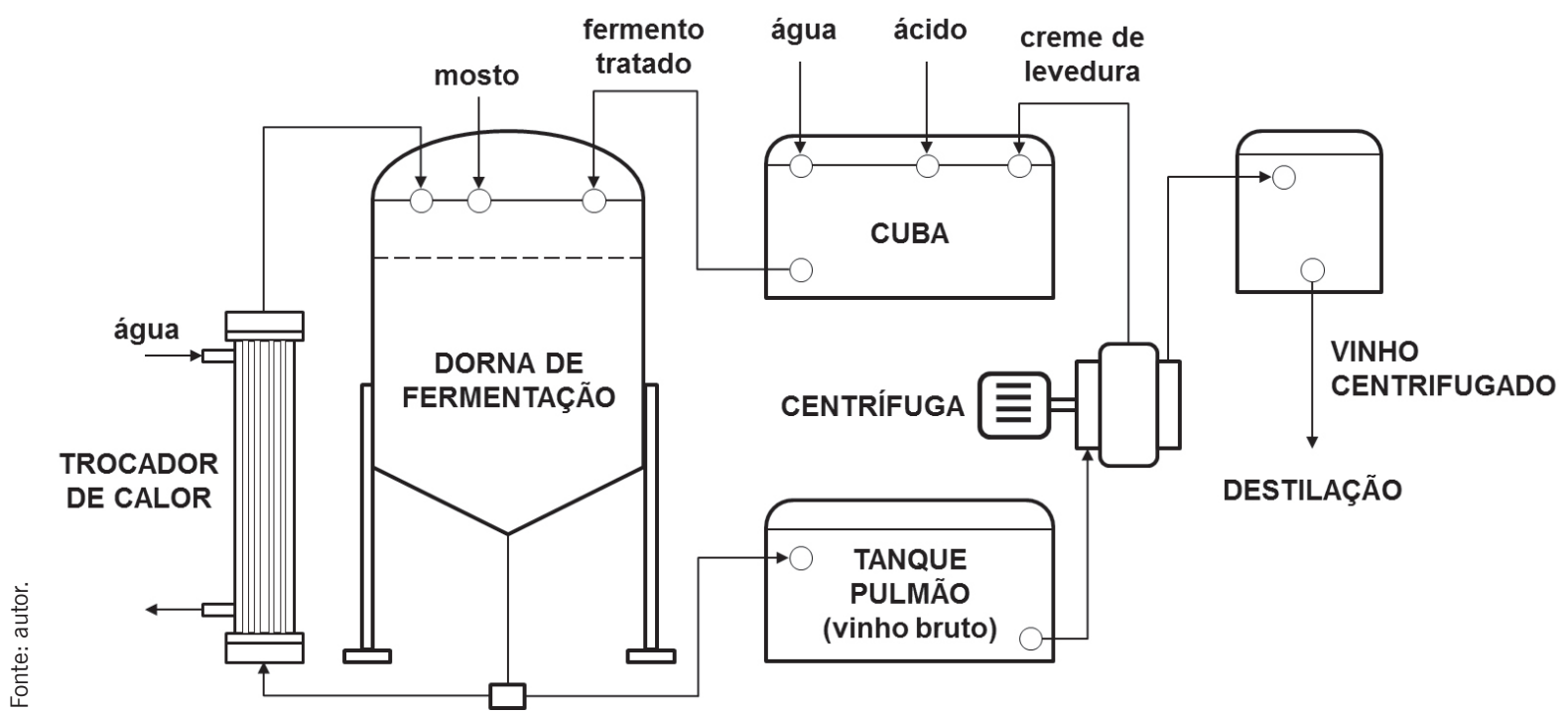

Figura 66: Método de fermentação Melle-Boinot utilizado nas usinas brasileiras.

A fermentação de alto teor alcoólico foi desenvolvida em parceria pela Fermentec, que se encarregou do processo e da seleção de leveduras mais tolerantes, e pela Dedini, que desenvolveu a planta industrial adequada ao processo, no qual empregou um chiller de absorção, introduzindo de forma inovadora na usina um fluxo de água gelada. A planta de demonstração, com capacidade de 20 mil litros de etanol/dia, foi instalada na Usina Bom Retiro, no estado de São Paulo (Figura 67) (Olivério, 2010a). Foram selecionadas e desenvolvidas leveduras mais tolerantes à alta concentração de etanol, possibilitando que a fermentação ocorresse até a $16^{\circ} \mathrm{GL}$, e reduzindo assim o volume de vinhaça a menos de $50 \%$ do obtido com o processo tradicional. 


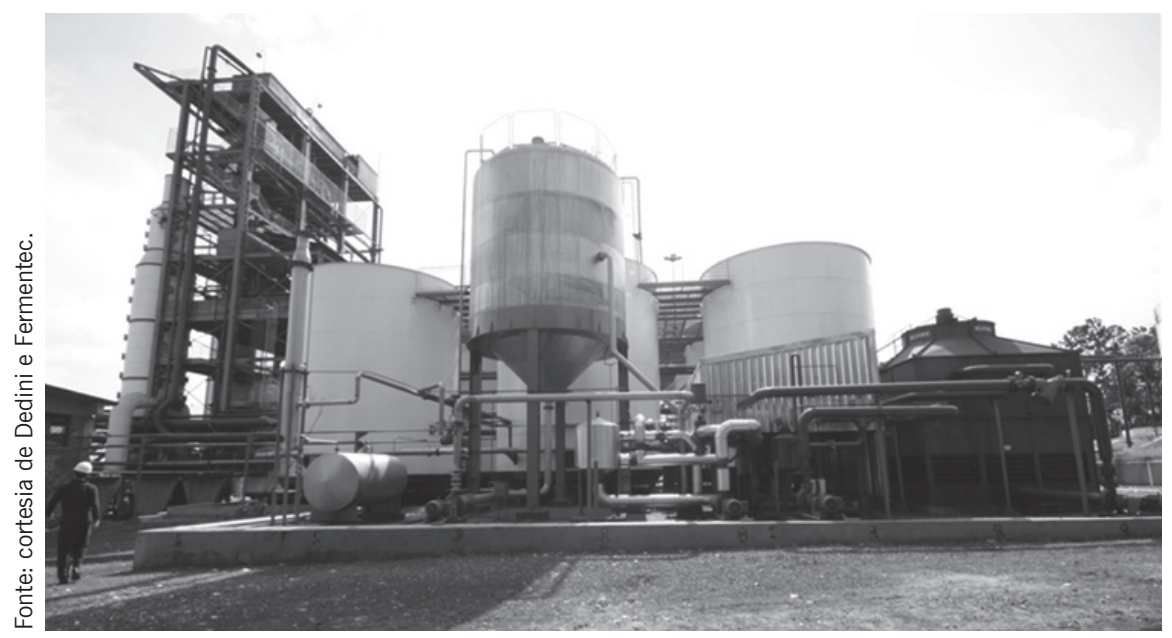

Figura 67: Visão geral da planta Ecoferm, com fermentação de alto teor alcoólico utilizando resfriamento com água gelada.

O processo foi denominado Ecoferm e gerou um pedido de patente internacional com cotitularidade das duas empresas (Amorim e Olivério, 2010).

Por outro lado, mesmo seguindo a estratégia de reduzir o volume de vinhaça produzido, ainda há que se dar um destino para ela. Nesse sentido, a biodigestão da vinhaça pode ser considerada como um pré-tratamento para a redução da carga orgânica, com o benefício da geração de biogás. No entanto, ainda hoje, poucas usinas ${ }^{25}$, como a São Martinho, utilizam a biodigestão termofílica para o tratamento da vinhaça. Trabalhos nessa área são desenvolvidos por Jorge Lucas Júnior, da Unesp Jaboticabal. O uso de biodigestores em outras áreas, como cervejarias, é considerado bem difundido.

Um importante projeto de biodigestão e uso energético da vinhaça teve tecnologia da planta desenvolvida no Brasil e resultou de um pool tecnológico, onde atuaram a PEM Engenharia com a engenharia básica,

25 Segundo informações fornecidas dor Alfred Szwarc, da Unica, entre as usinas que têm adotado a biodigestão de vinhaça estão hoje: a Usina Ester; a Usina Companhia Alcoolquímica Nacional, em Pernambuco, em parceria com a CETREL; e o Grupo JB (ver <www.biomassabioenergia.com.br/ noticia/no-nordeste-vinhaca-da-cana-produz-eletricidade/20120409083753_L_410>); e uma unidade no Paraná, parceria entre a Coopcana e a Geoenergética (<http://revistadinheirorural.terra.com.br/secao/agronegocios/energia-sustentavel-da-cana $>$ ). 
os especialistas em biodigestão Karl Richbieter e Ivo Richbieter, a Codistil Dedini como fabricante de planta e a Automatus como fornecedora do compressor de biometano de alta pressão. O pool desenvolveu e implantou na Usina São Luis, Pirassununga, SP, na época uma das empresas Dedini, uma unidade para desenvolvimento de processo, em pequena escala, onde se comprovou a viabilidade técnica e se levantaram os parâmetros de engenharia para o projeto da unidade industrial.

Após os entendimentos entre as partes, o processo tecnológico ficou de propriedade da Codistil Dedini, que, em 1986, implantou a primeira planta industrial do gênero na Usina São João, em São João da Boa Vista (SP), também à época uma empresa Dedini, com financiamento do BNDES destinado a soluções pioneiras, e uma planta Methax para a produção de $6.500 \mathrm{Nm}^{3} /$ dia de biometano, com as seguintes características:

- tratamento de um terço da vinhaça da usina por biodigestor anaeróbio, utilizando um reator de fluxo ascendente com leito de lodo e produzindo biogás e um efluente biodigerido;

- a biodigestão atua sobre a matéria orgânica presente na vinhaça e praticamente não atua sobre os demais componentes. Dessa forma, o efluente biodigerido mantém as qualidades fertilizantes principalmente por não perder o seu teor em potássio;

- purificação do biogás e concentração do biometano;

- compressão do biometano até 220 bar;

- abastecimento da frota da usina com o biometano comprimido.

O biometano abasteceu toda a frota canavieira da Usina São João, composta de 29 caminhões, 17 veículos leves (Olivério; Miranda, 1989) e 1 trator, além de um terço da frota de ônibus do transporte urbano da cidade de São João da Boa Vista, em um convênio envolvendo a municipalidade, a Mercedes-Benz, a empresa de ônibus urbano, a distribuidora de combustíveis Ipiranga e a própria Usina São João.

A planta Methax operou comercialmente de 1986 a 1995, após o que foi desativada devido ao fato de que nesse intervalo ocorreu uma mudança no perfil dos caminhões canavieiros, que de até $200 \mathrm{CV}$ (para os quais existiam disponíveis motores a gás a ciclo Otto) passaram a utilizar motores da ordem de $400 \mathrm{CV}$, não disponíveis no mercado. 
Essa planta Methax, contudo, comprovou que se obtém maior retorno sobre o investimento para o biogás/biometano substituindo o diesel na frota canavieira (Olivério, 2011a). As Figuras 68, 69 e 70 a seguir se referem ao Projeto Methax e foram fornecidas por José Luiz Olivério.

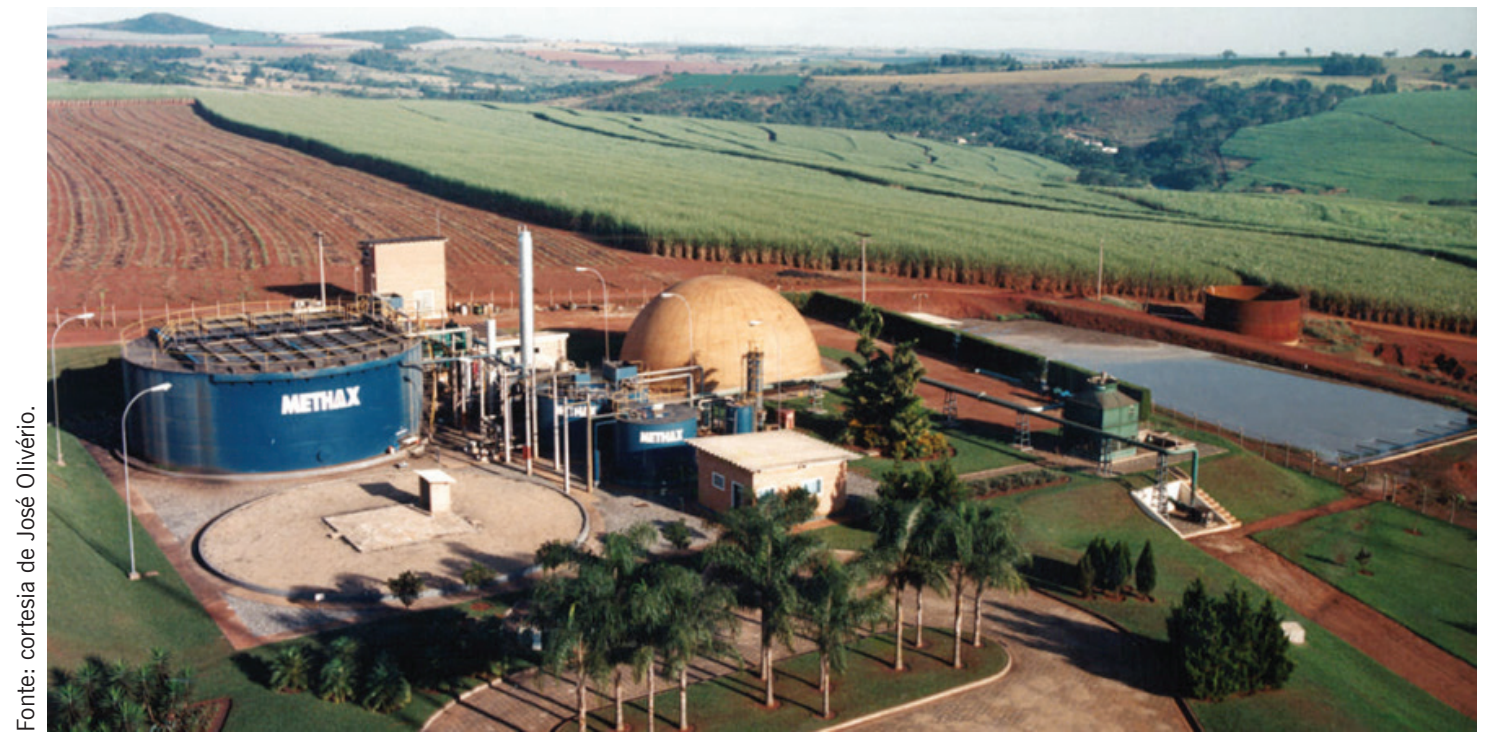

Figura 68: A planta Methax instalada na Usina São João, em São João da Boa Vista (SP).

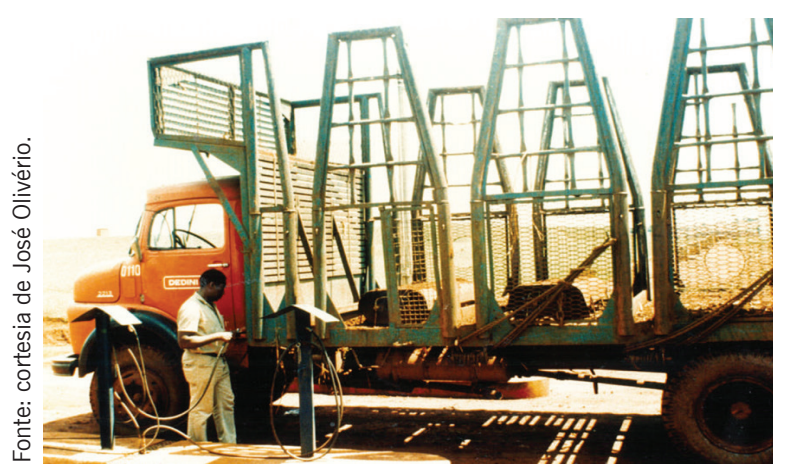

Figura 69: Caminhão canavieiro sendo abastecido de bioetanol.

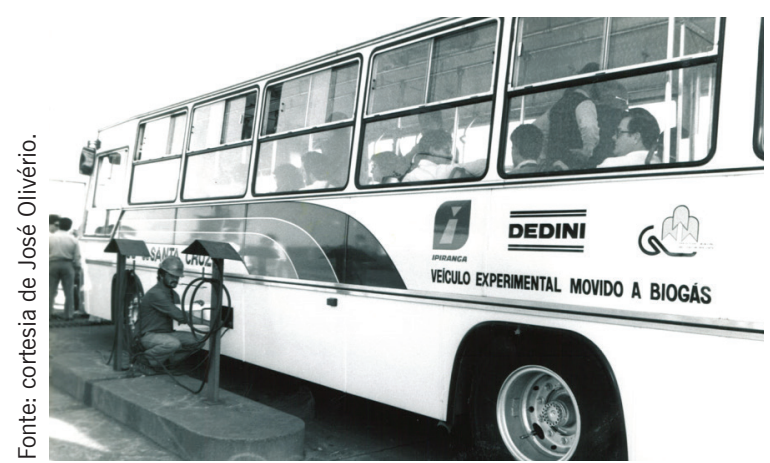

Figura 70: Um terço da frota de ônibus de São João da Boa Vista foi abastecido por biometano a partir de julho de 1989. 
Atualmente, existem cerca de duzentos biodigestores no Brasil, implantados por exigência ambiental, em outros setores não canavieiros.

A solução mais adotada no Brasil para a disposição da vinhaça foi a fertirrigação. No entanto, devem ser estimulados estudos que possibilitem reduzir as quantidades desse efluente, como o desenvolvimento de leveduras mais tolerantes ao etanol, ou concentrando a vinhaça. Nesse sentido, a Fermentec tem envidado esforços para aumentar o teor alcoólico utilizando novas leveduras, inclusive com financiamento da Fapesp. Foram obtidos teores alcoólicos de $16 \%$ (v/v), com a redução da vinhaça pela metade. O impacto econômico dessa inovação foi mostrado por Henrique de Amorim na XVI Conferência Internacional da Datagro sobre açúcar e etanol.

\section{Programa Probiodiesel}

A exemplo do Proálcool, foi criado o Programa Nacional de Produção e Uso de Biodiesel (Probiodiesel) por meio da Portaria MCT n. 702, de 30 de outubro de 2002. Em função disso, o governo federal definiu metas para impulsionar a produção de óleos vegetais (1,3 bilhão de litros), de plantas para transesterificação e também de misturas biodiesel/diesel, começando pela mistura B2 (2\% de biodiesel e $98 \%$ de diesel) ${ }^{26}$ e, em 2014 , atingindo a B7.

Exemplo importante de interação entre pesquisa e indústria se encontra na planta de biodiesel da Agro Palma, em Belém (PA). Tratou-se de um negócio pioneiro, a primeira planta de biodiesel adquirida no Brasil em regime de concorrência. Por solicitação da Agro Palma, foi desenvolvida na UFRJ pelo prof. Donato Aranda um processo para a produção de biodiesel tendo como matéria-prima os ácidos graxos, subprodutos da produção de óleo de palma. O processo utilizava um catalisador heterogêneo e tinha rota tecnológica flexível, etílica ou metílica, isto é, alternativamente podia ter como segunda matéria-prima o etanol ou o metanol. Esse desenvolvimento, em nível de laboratório, gerou uma patente.

Diretamente a partir das equações de processo e demais dados obtidos no laboratório, a Dedini, que ganhou essa primeira concorrência realizada no Brasil em plantas de biodiesel, concebeu, projetou e forneceu no regime turn-key, em 2005, a planta de biodiesel com capacidade de 10.000 t/ano; ou seja, diretamente da escala de laboratório para a industrial. A Figura 71 apresenta a planta (Olivério, 2009b).

26 Ver < www.mme.gov.br/programas/biodiesel/menu/programa/objetivos_diretrizes.html>. 


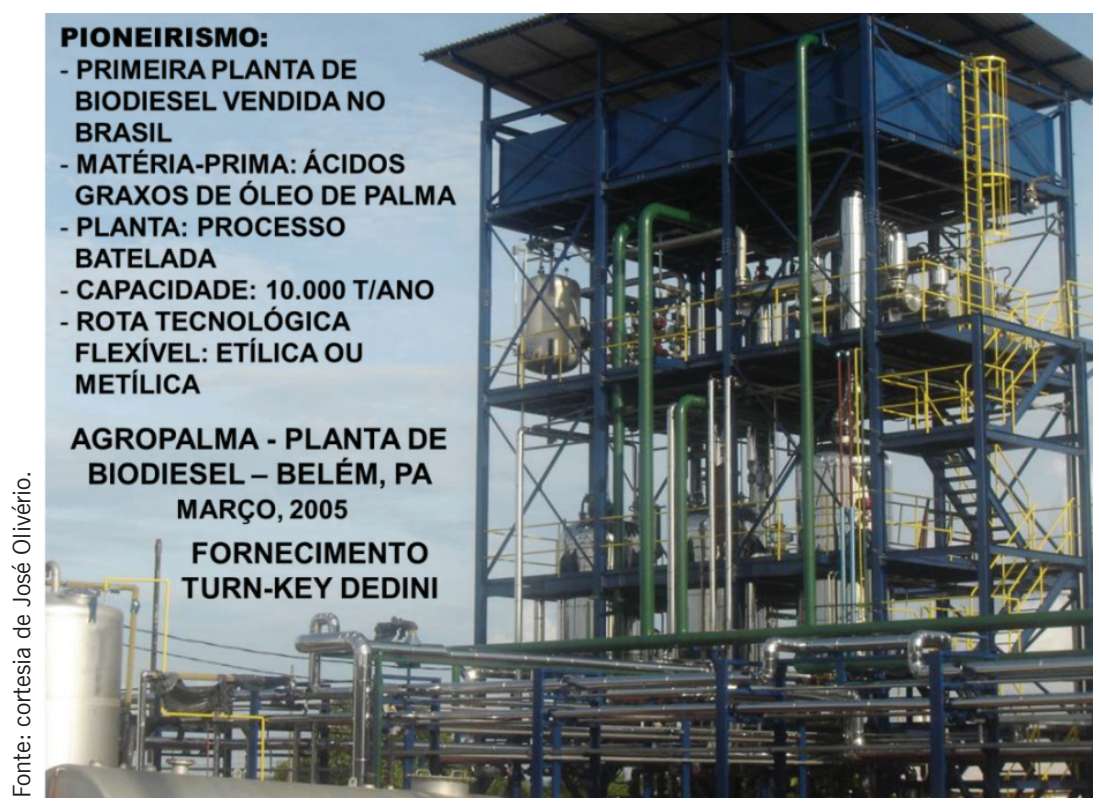

Figura 71: A planta de biodiesel - Agro Palma - do laboratório para a solução industrial.

O Programa de Biodiesel gerou para a Dedini a oportunidade de desenvolver uma significatica inovação mundial: a integração biodiesel-bioetanol. A ideia desse desenvolvimento ocorreu ao se analisar as inúmeras sinergias existentes entre as cadeias produtivas e os processos desses dois biocombustíveis, levando à concepção de uma planta de produção de biodiesel integrada à usina sucroenergética (Figura 72).

Essa solução pioneira foi transformada em realidade, com a Dedini projetando, fabricando e implantando na Usina Barralcool uma

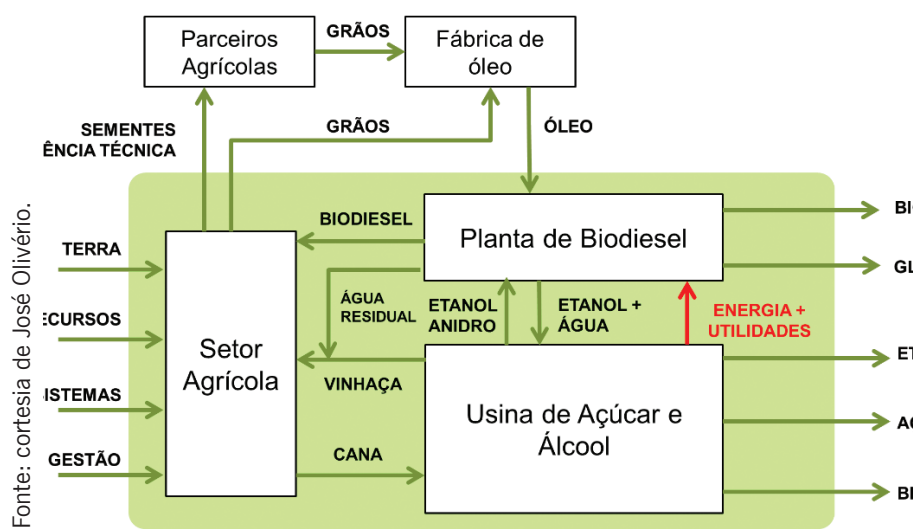

Figura 72: A produção integrada de biodiesel na usina Barralcool - Sinergias, integração agrícola e industrial. unidade produtora de biodiesel. 
Dessa forma, a Barralcool se transformou na primeira usina 4 Bios do mundo, por produzir bioaçúcar, bietanol, bioeletricidade fornecida à rede de distribuição e biodiesel.

O trabalho foi apresentado como um paper no XXVI Congresso do ISSCT e ganhou o prêmio Best Paper na seção de coprodutos (Olivério; Barreira; Rangel, 2007), sendo incluído no livro Bioetanol da cana de açúcar. A Figura 73 apresenta a Usina Barralcool, a usina 4 Bios.

\section{2: cria-se o JornalCana}

Criado em 2002 pelo grupo ProCana Brasil, o JornalCana (Figura 74) possui circulação mensal no formato digital (internet) e impresso e apresenta as novidades técnicas, colaborando para o desenvolvimento do setor sucroalcooleiro. Nele são publicadas informações sobre as empresas, universidades, centros de pesquisa, eventos, mercado e relações com o governo, sendo assim o principal canal aberto com informações relevantes do setor ${ }^{27}$.

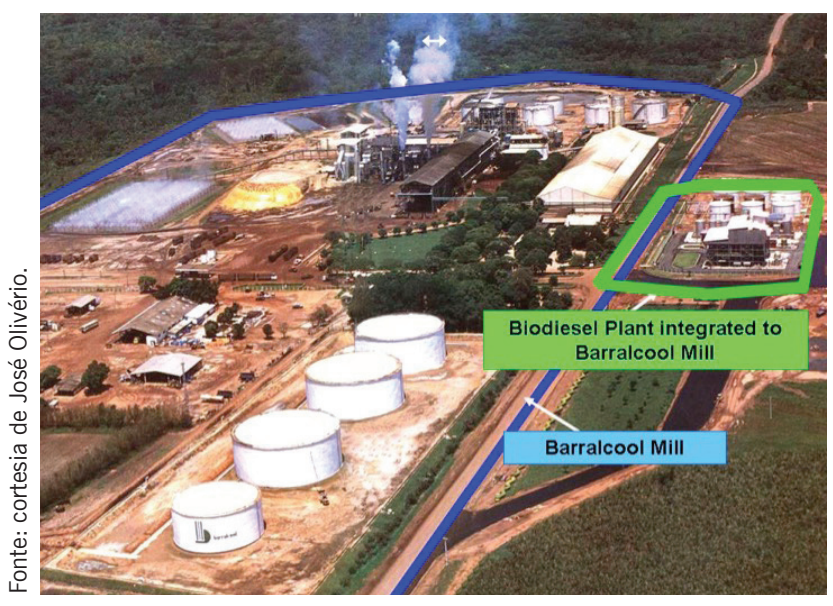

Figura 73: A Usina Barralcool. Vista aérea da planta de biodiesel integrada à Usina Sucroenergética.

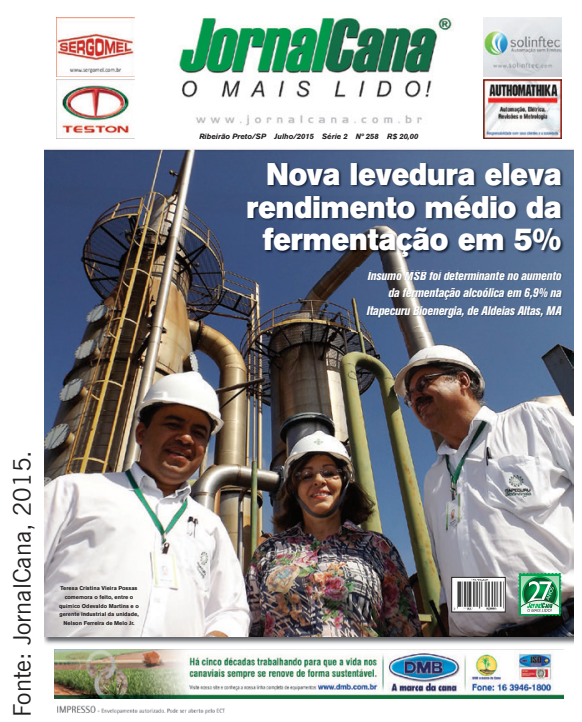

Figura 74: JornalCana.

27 Ver <www.jornalcana.com.br/>. 